\title{
8.12 Проблема моделювання розвитку особистісної надійності у навчанні майбутніх підприємців
}

Підприємництво, як особливий вид світогляду, характеризується унікальними поглядами і методами до прийняття домінантних рішень, які реалізуються на практиці, що потребує приділяти велику увагу у навчальному процесі при підготовці майбутніх фахівців підприємницької діяльності.

Значні зміни в соціально-економічних умовах життя суспільства спричинила сучасна світова економічна криза. Вона посилила динаміку процесів суспільно-політичного життя нашої країни, а це призвело до значних зміни у виробничих силах, що вплинуло на організаційні стосунки у малих групах і тим самим детермінувало зміни психічних структур особистості. Трансформаційні процеси сьогодення ще 3 більшою силою висвітлили як актуальну та надзвичайно необхідну для дослідження з боку науковців проблему особистісної надійності суб'єкта професійної діяльності, бо особистісна надійність має вагоме значення в регуляції життєдіяльності різних індивідуальних та групових суб'єктів.

Особистісна надійність $є$ фундаментальною, атрибутивною ознакою особистості, яка характеризує іiі здатність до прогнозованої відповідальної поведінки, пов'язаної з реалізацією соціальних взаємин відповідно до групових норм та цінностей. Відомо, що здатність до прогнозованої відповідальної поведінки вимагає значних зусиль навчального процесу майбутніх фахівців.

Аксіомою $є$ те, що спроби швидко створити вільну ринкову економіку в країні, в якій десятиліттями панував авторитарний режим, заздалегідь приречені на провал. Така країна повинна пройти етап поступової лібералізації й виховання поваги до свободи особистості, щоб у суспільстві розвинулися прагнення до незалежності й дух підприємництва.

Підприємництво розглядається як діяльність людини в інтенсивних суспільно-значущих ситуаціях, підсумком яких $є$ нова структура в господарській та інших сферах матеріально - духовного виробництва, в яких реалізується суб'єктний потенціал людини [718, с. 15-16]. 
Підприємництво передбачає діяльність підприємця, який є творцем власної справи і який може започаткувати як нову професію, так і галузь в існуючих професіях, де він $\epsilon$ соціальним новатором та трансформатором соціокультурного середовища.

Вважаємо, що онтогенез розвитку надійності корелює із розвитком суб'єктності, як властивості людини бути джерелом власної свідомої активності, творити свій внутрішній та зовнішній світ. Цьому повинний сприяти i навчальний процес майбутніх фахівців.

Таким чином, надійність, надаючи свободу в межах певної діяльності, водночас покладає відповідальність за виконання системи дій, операцій. Рольова надійність обмежує свободу заданою ззовні соціальною роллю, відповідальність - за виконання цієї ролі; при особистісній надійності людини індивідуальна свобода - у межах самостійно створеної ролі, моральна відповідальність; діяльнісний рівень розвитку надійності та їі межі свободи опосередковуються межами власного життя, відповідальністю за власну життєтворчість. Рефлексивний рівень розширює свободу до меж заданої історичної культури, а змістом відповідальності є розвиток власної надійності. Діалогічна надійність розширює свободу до міжкультурного простору, покладаючи тягар відповідальності на розвиток людства.

Отже, особистісна надійність людини - це властивість людини, яка характеризує ії здатність до прогнозованої поведінки, пов'язаної з реалізацією соціальних взаємин у відповідності з суспільними нормами та ідеалами, а також власним відповідальним вибором.

Особистість, яка характеризується особистісною надійністю, здатна бути автономним носієм загальнолюдського досвіду та історично вироблених людством і відображених у культурі форм поведінки й діяльності. Діалектика взаємодії особистісної надійності людини та культури полягає, на наш погляд, у тому, що культура детермінує розвиток та становлення особистісної надійності людини, а особистість є носієм та творцем культури. В. Франкл довів за результатами досліджень у галузі неврології та психіатрії міру залежності 
людини від біологічних, психічних і соціальних умов; водночас людина здатна кинути виклик найбільш важким умовам, які лише тільки можливо собі уявити [719].

Узагальнюючи теоретичні дослідження проблеми особистісної надійності людини, зазначимо, що змістовими властивостями, які складають іï основу, є певні віково-статеві, нейродинамічні властивості, конституційні та фізіономічні особливості, риси характеру, особливості когнітивної сфери, ціннісні орієнтації людини, зокрема, відповідальність, стійкість, вольові якості, почуття обов'язку, дисциплінованість.

Окрім цього, вагомим аспектом питання, що розглядається, є власне визначення особистісної надійності людини як нормативно-ціннісного поняття в контексті самоактуалізації особистості. Так, до найважливіших особистісних характеристик Г. Балл, виходячи з розуміння особистості як системної якості людського індивіда, включає, передусім, найбільш істотні його характеристики, а саме «особистісні орієнтири», що забезпечують функціонування людини як автономного учасника суспільного буття й суб’єкта культури. До таких характеристик учений зараховує особистісну надійність людини, розуміючи під цим терміном таку цілісну якість особистості, що визначає готовність останньої до доброчесного виконання конкретних суспільних функцій.

Автор зазначає, що «кількісно особистісну надійність людини можна оцінити ймовірністю, з якою вдається передбачити поведінку особи з реалізації взаємин, що склалися в неї з іншими учасниками суспільного буття (індивідами, групами, організаціями), а також з нормами та ідеалами, котрі регулюють (або мають регулювати) їі поведінку» [720, с. 461-474]. Отож, даній характеристиці надається, поряд із концептуальним, також функціональне, суто поведінкове, визначення.

Формуючи сутність і психологічний зміст особистісної надійності, дослідник Г.О. Балл виходить «із розуміння особистості як такої системної якості людського індивіда, що охоплює стійкі (принаймні сталі) характеристики, 
істотні для його функціонування, як відносно автономного учасника суспільного буття, а також... як суб’єкта культури» [720].

Звертаючись до питання про надійність працівника на виробництві, в своїх дослідженнях Г.О. Балл розглядає ії як окремий вид особистісної надійності. «Адже в даному разі з'ясовується, чи можна розраховувати на достатню стійкість працівника в реалізації взаємин, у які він увійшов із нормами, що регулюють виробничий процес (прийнявши їх до виконання), а також з організатором виробництва і з партнерами по праці». Конкретизуючи психологічний зміст особистісної надійності як феномену, український психолог пов'язує його 3 вимогами щодо виконання діяльності в тих чи інших іiі аспектах, зокрема, на рівнях: а) правильного виконання чітко заданих операцій (скажімо, при роботі на конвеєрі); б) успішного розв'язання задач різного характеру, різного ступеня складності і проблемності; в) реалізації певних смислів, пов'язаних зі ставленням до конкретних людей, соціальних спільнот, сфер діяльності, культурних і духовних цінностей; г) пошуку й реалізації людиною особливого смислу, а саме - унікального сенсу свого життя [721, с. 109-114].

У навчальному процесі слід чітко розуміти, що у даному випадку 3'ясовується, чи можливо планувати необхідну стійкість співробітника в реалізації відносин, в які він увійшов із загальновизнаними нормами, що регулюють виробничий процес (прийнявши їх до виконання), а також 3 організатором виробництва і з партнерами по праці.

Поняття особистісної надійності, в окресленому вище трактуванні, постає, попри його операціональності, гуманітарно й етично навантаженим. Тому у навчальному процесі слід зосередитися на психологічному змісті особистісної надійності. Залежно від вимог до результатів діяльності особи, від того, які саме параметри цих результатів мають бути надійно передбачувані, найбільш потрібними постають ті чи інші компоненти у структурі діяльності (і поведінки як іiї зовнішнього вияву). Відповідно зазнає змін і психологічна конкретизація загальної вимоги передбачуваності поведінки (а отже, особистісної надійності). У своїй сукупності (точніше, інтегрувавшись у єдину систему) ці якості 
утворюють той конкретний вияв особистісної надійності, який відповідає високій мірі професіоналізму: - на рівні виконання певних смислів, пов’язаних зі ставленням до конкретних людей (зокрема, з переживанням щодо них почуттів дружби, любові, морального обов'язку), а також із подібним ставленням до соціальних спільнот, сфер діяльності, культурних і духовних цінностей; - на рівні знайдення (часом через довгі пошуки) й реалізації людиною особливого смислу, а саме унікального сенсу свого життя. У наведеному переліку рівні розміщено в напрямку підвищення ступеня узагальненості управління поведінкою. Певних коментарів потребує найвищий у запропонованій ієрархії рівень, який передбачає вірність сенсові свого життя. Слід зазначити, що цей сенс може й не фіксуватися чітко у свідомості його носія (не говорячи вже про інших людей) і лише інтуїтивно вгадуватися ним - i тим не менш слугувати могутнім регулятором, критерієм оцінювання й важелем удосконалення поведінки.

Стосовно сенсу життя, як специфічного смислу, окремі смисли, що були раніше основою «зобов’язань» особи, можуть або постати (можливо, перетворившись) його гранями чи гармонійними доповненнями, або бути подолані як несумісні з ним, або, попри наявні суперечності, зберігатися, створюючи напруги в житті особистості. Продуктивним може бути такий сенс життя, який, становлячи своєрідний відгук на нагальні потреби навколишнього світу, водночас узгоджується з індивідуальністю людини, передусім зі сталими, такими, що не можуть бути цілеспрямовано змінені, рисами їі особистості. За цієї умови сенс життя збігається 3 покликанням людини. Досягнувши вершин професіоналізму, людина «робить не те, що схвалюють інші, не те, що інші чекають від неї, не те, за що інші іiі засуджують. Вона робить те, до чого призначена». У вказаному визначенні згадуються «норми..., котрі регулюють (або мають регулювати) їі (особи) поведінку». Тож до них, безумовно, належать, поряд із нормами, що накладаються ззовні й розраховані на багатьох осіб, також особистісні норми, модифіковані або сформовані самою особою. Узгодженість поведінки із сенсом життя становить чи не найважливішу особистісну норму. $€$ 
цілком закономірним, що вірність сенсові життя часом виражається в манері виконання, яка зовні здається непослідовною й, отже, не подібною до фактів, що їх найчастіше пов’язують із поняттям особистісної надійності. Адже в науці досить часто теоретичне осмислення й узагальнення понять (таких, наприклад, як «число» або «множина» в математиці) дозволяє поширити їх на об’єкти, багато в чому не схожі на ті, з якими ці поняття пов’язувалися спочатку [722, с. 93-97].

Світоглядною й методологічною основою розуміння Г.О. Баллом особистості є принцип раціогуманізму, який становить у найширшому контексті важливу передумову «успішного розвитку й позитивного впливу на суспільну практику» психологічної науки в цілому. Вчений уважає, що відповідно до цього принципу є актуальним «з’ясування того, як поєднати у психологічній царині гуманістичну налаштованість із конструктивним використанням засобів раціонального пізнання». Водночас він зазначає, що «раціоналізм, трактований у загальному сенсі як цінування розуму і спирання на нього, постає однією зі сторін гуманізму». При цьому слід орієнтуватися не на механістичні, дисгармонійні форми інтелекту людини, що дискредитували себе «у війнах i готуванні до них, у насаджуванні екологічно шкідливих технологій, у корисливому маніпулюванні свідомістю і поведінкою великих мас людей і т.П.», а на «збалансований, гармонійний інтелект», окреслений у контексті поняття культури. І це закономірно, адже культура - це «сукупність людських функцій (та засобів їх реалізації), спрямованих на забезпечення соціальної пам'яті та соціально значущої творчості; носіями культури є: по-перше, людство в цілому; по-друге, людські спільноти; по-третє, окремі особи». Відповідно, культура постає як «єдність складників двох типів: а) нормативно-репродуктивних, тих, що забезпечують усталеність засобів і способів функціонування людських спільнот та окремих осіб, зв’язок між попередніми і наступними поколіннями (ці складники часто пов’язують із поняттям цивілізації, в одному з його численних, як і в поняття культури, тлумачень); б) діалогічно-творчих, завдяки яким відбувається оновлення й розвиток людського суспільства» [721, с. 112]. 
Г.О. Балл звертає увагу на величезну суспільну вагомість особистісної надійності. Вона має також й економічне значення, тому що постає передумовою формування й функціонування так званого соціального капіталу. За концепцією Дж. Коулмена, подібно до фізичного капіталу, втіленого в тих чи інших матеріальних формах, і людського капіталу, що знаходить вияв у навичках i знаннях індивідів, наявний у їхніх взаєминах, соціальний капітал «полегшує виробничу діяльність. Наприклад, група, всередині якої існує повна надійність і абсолютна довіра, здатна здійснити набагато більше, порівняно із групою, що не має таких якостей» [721, с. 114].

Зараз, в умовах розвитку та становлення у навчальному процесі економіки «знань», головною рисою людини, що розвивається у ринкових відносинах, вважається дієздатність до незмінного саморозвитку, інноваторської зміни реальності, пошуку та реалізації сучасних способів здійснення соціальноекономічної, підприємницької, управлінської, комерційної діяльності. Заміна змісту діяльності з репродуктивної, властивої для промислової, ресурснозалежної економіки, на творчий процес - головна ознака сучасних економічних процесів та тенденція в суспільстві, які визначають роль і простір людини в новітній економіці. Особистість виступає рушійною силою становлення соціального розвитку за рахунок соціально-економічної активності та підприємливості, які постають як результат перебудови структури внутрішнього світу людини. При цьому економічний прогрес, природно, залишається важливою умовою формування нового господарського порядку, втім сутнісною умовою вважається зміна ціннісних орієнтирів людини, створення умов, в яких ключовим моментом стає реалізація ії внутрішнього потенціалу [723, с. 164-175].

Таким чином, людина, як феномен ринкової економіки, вважається не лише виробником і споживачем, не лише власником і найманим працівником, але й людиною-творцем, джерелом інноваційної енергійності, носієм духовновольового потягу до перетворення, до самореалізації власних внутрішніх необхідностей i уподобань. Розвиток такого особистісне міцного суб'єкта підприємницької енергійності в нашій країні, яка розташовується під впливом 
згаданих нами вище архаїчних ідейних та ідейно-ціннісних конструктів, вважається дуже важким і важливим завданням. Це обумовлює загальну потребу теоретичної розробки способів адаптаційно-креативної соціалізації української сучасності до системи ринкових відносин, що розвиваються в нашому суспільстві і в світі. Сучасні обставини формування культури ринкової економіки в Україні вимагають від особистості інтенсивної позиції в системі фінансових відносин, креативної взаємодії з іншими їі суб’єктами [723, с. 166]. Модифікація ціннісних уявлень, масова перебудова суспільних стандартів та зміна систем цінностей вважається важливою соціально-психологічною задачею. Зміна стандартів у глобальній свідомості буває складною і нерідко розуміється окремими групами людей як зміна стандартів, втрата сенсу життя. Утворені новітні стандарти непросто пристосовуються, суперечливо сприймаються, часом навіть заперечуються. Власне, що стосується системи цінностей, то вона в цьому процесі засновує новітні і потрібні соціумом ціннісні орієнтації, нові ієрархії цінностей підприємницької діяльності.

Зараз виділяють три полюса в глобальній оцінці моралі у свідомості людей: стан морального вакууму, де домінує вседозволеність; погоджуються лише тільки значення ринкових відносин, де всесвіт оцінюється категоріями вартості, ціни, коштів, ділових комунікацій; малозначна частка соціуму продовжує наслідувати класичні знання нашої культури з відповідним негативним ставленням до людей 3 іншим ставленням до духовних цінностей. У XXI столітті людина, як носій цінностей класичної культури, втрачає власні колишні значущі якості, потрапляє в жорстку підневільність від стандартів нав'язуваній їй поведінки. В силу об'єктивних подій вона повинна підключатися в сувору конкурентну боротьбу за виживання, речові блага, дотримання незвичайних форм духовно-практичної роботи. Ставши жертвою цих подій, люди страждають від дискомфорту, автономності духовного життя, класичних еталонів державної та світової культури [723, с. 168]. Усвідомлюючи, що найвищою цінністю передового цивілізаційного процесу вважається людина, іiі права і свободи, слід підкреслити, 
що власне в критеріях становлення глобалізаційного передового світу набуваються нові спільні значення, які важливі для життя в єдиному соціумі.

Поміж групи універсальних соціально-економічних цінностей - це право будь-якої людини на самозабезпечення. Маючи головні права i свободи передового демократичного суспільства, людина має можливість проектувати й будувати своє майбутнє в системі реальної життєдіяльності та професійній сфері. Зараз у світі проблематика підприємницької сутності стоїть перед людиною досить гостро, в тому числі, і в економічно розвинених державах. Питання про суть бізнесу, ієрархію цінностей, роль і простір людини в сфері підприємницької діяльності все частіше задають для себе як окремі робітники, так і очільники компаній. Ключовим завданням передового бізнесу вважається створення специфічної для певної компанії фінансової культури, яка була б адекватним вираженням іiі ділової стратегії. На базі нової підприємницької культури лежить принцип людино-центричності та моральності всякого передового бізнес-процесу [723, c. 168-172].

Кожна людина, група або суспільство в цілому перебувають на певному етапі свого особистого й духовного розвитку. Залежно від цього цілі, яких людина або група досягають, ставлячи перед собою, відповідають тим рівням свідомості й буття, у контексті яких такі цілі ставляться. Так, для підприємця цілі концентруються навколо постачання матеріальними й фінансовими ресурсами власної фірми, отримання прибутку від бізнесу, забезпечення власного добробуту, родини, певною мірою турботу про місце свого проживання (місто, область), процвітання економіки власної держави. У такому контексті можна виділити, як мінімум, чотири рівні цілепокладання - особистий, родинний, підприємства, регіону і держави. Ні в якому разі жодна 3 них не $\epsilon$ «гіршою» або «кращою» 3 погляду соціуму в цілому, але вони ставляться з різних рівнів буття, усвідомлених самою людиною. Цілі висуває будь-яка людина, однак, для правильного розуміння їх необхідно, напевно, чітко знати, з яких рівнів вони формулюються. Цілі людини визначаються іiі цінностями, осмисленими відповідно до певної системи потреб, в утворенні якої головну роль, як правило, відіграє оточення. 
Допомогти в оцінці рівня цінностей людини може концепція вертикального розвитку, котра була сформульована Ж. Гебстером, який висунув ідею, що в своєму розвитку як людство в цілому, так і окрема людина проходить через певні етапи, що характеризуються радикальними змінами структури свідомості [724]. Дослідник Ж. Гебстер передбачив бурхливе розповсюдження різноманітних вертикальних систем розвитку в другій половині XX століття - від моделі ієрархії потреб А. Маслоу до комплексної інтегральної карти AQAL (All Quadrant All Level) К. Уілбера [725].

Одним із учених, який здійснив найбільший внесок в остаточне оформлення концепції вертикального розвитку, $є$ видатний американський психолог К. Грейвз [726]. Він назвав свою концепцію «теорією емерджентних циклічних рівнів існування» (соціально-еволюційна теорія спіральної динаміки). В якості основної характеристики розвитку К. Грейвз обрав ціннісні орієнтири особистості. Дослідник не тільки описує поступальну зміну рівнів розвитку особистості, які характеризуються якісними змінами ціннісних орієнтирів людей у міру зростання складності їх мислення, а й формулює закономірності зміни етапів цього розвитку.

Спіральна динаміка інтегрується та трансформується до загальної моделі, не спростовуючи попередні теорії. Вона може включати й основні акценти піраміди А. Маслоу (задоволення базових потреб) та постулати, які засновані на моделі життєвого циклу І. Адізеса, що охоплює еволюцію потреб від інстинктів виживання, рівня «розвинутого егоїзму», індивідуалізму, раціоналізму й передбачає перехід до інтегрального рівня [727].

Сьогодні модель спіральної динаміки - це така модель, яка динамічно розвивається і привертає увагу вчених і громадськості як на Заході, так і в Україні, зокрема, у роботах В.О. Пекаря [728]. Він популярно виклав теорію спіральної динаміки у прикладному аспекті розуміння підприємництва, бізнесу, менеджменту, стилів лідерства та управлінських культур, інструменти їх зміни. К.О. Линьовим було використано пояснювальні можливості моделі спіральної динаміки щодо розумінні феномена лідерства в системі державного управління [729]. В.В. Ворожбит простежив зв'язок між стилем управління, ринковим 
середовищем, видами діяльності підприємств та рівнем корпоративної культури відповідно моделі спіральної динаміки [730]. Спираючись на методологію теорії спіральної динаміки, Є. Пулман визначив рівень розвитку людини стосовно до політики й соціальної сфери в українському суспільстві, використовуючи матеріали Європейського соціального дослідження, дослідження «Український характер» ЦСД «Софія» i результати опитування Українського Інституту Майбутнього (опитування проводилося серед людей виборчого віку) [731].

Інтегральна модель спіральної динаміки відображає виникнення й розвиток систем цінностей, які існують спільно, по черзі визначаючи стратегію розвитку та впливаючи на вибір системи управління. Концепція передбачає схему основних ціннісних мімів світу. Міми - інформаційні пакети, які, подібно до вірусів, переносяться від одного розуму до іншого, від громади до громади. Рухи й зупинки у процесі спіральної еволюції можуть відбуватися в будь-якому 3 напрямків - як вгору, так і вниз (еволюція чи інволюція). Спіраль моделі науковця К. Грейвза не має верхньої межі; до неї необхідно додавати нові літери, цифри й кольори як нові рівні психологічного існування, що проявляються в людській природі. Під цінностями розуміються традиційні і ключові цінності соціальних корпорацій, загальнолюдські й сімейні, тобто, не матеріальна сторона справи. Відповідно до теорії К. Грейвза, управління цінностями допомагає визначати причини виникнення конфліктів і розширює можливості мотивації, стимулювання персоналу [726].

Ось ще кілька постулатів, на яких базується модель вертикального розвитку К. Грейвза:

- людина - це відкрита система, що розвивається; можливості до розвитку та адаптації щодо різних обставин безмежні;

- у процесі розвитку людина (як і суспільство в цілому) послідовно проходить через рівні розвитку, кожен з яких якісно відрізняється від інших;

- стани на одному рівні розвитку стають навичками на наступному рівні. Те, що на більш низькому рівні $є$ разовим досягненням, вимагаючи від людини 
спеціальних зусиль, на наступному рівні розвитку стає звичним, легко відтвореним навиком;

- кожен наступний рівень не відкидає, а включає в себе попередній. Стереотипи поведінки на більш низькому рівні можуть вільно відтворюватися на наступному рівні. Тобто, у міру розвитку людина стає більш вільною у виборі найбільш доречних стратегій поведінки й застосування тих чи інших навичок відповідно до ситуації;

- людина (або суспільство в цілому) адекватно й позитивно сприймає тільки ті способи мотивації, методи управління, правила поведінки та етичні принципи, які відповідають їхньому рівню розвитку;

- на кожному рівні можна перебувати нескінченно довго. Якісний розвиток і перехід з одного рівня розвитку на інший не гарантований, він вимагає певних зусиль в освоєнні нових навичок, необхідних для переходу на наступний рівень [726, c. 148-150].

При цьому розвиток відбувається не поступово. Наприклад, за мірою свого розвитку людина долає послідовність криз. Криза розвитку - це стан, при якому подальший розвиток стає неможливим у межах сформованих стереотипів поведінки й набору існуючих навичок.

Рівні розвитку в теорії К. Грейвза описуються за допомогою парадигм свідомості (які для зручності кодуються різними кольорами: бежевий, фіолетовий, червоний, синій, помаранчевий, зелений, жовтий, бірюзовий). Це система координат у просторі картин світу. Ці парадигми свідомості, або ціннісні комплекси, що включають духовні вірування, культурні ідеї, моральні принципи, моделі навчання тощо, з’являються по мірі виникнення потреби в них у процесі соціокультурної еволюції.

Парадигми виникають спочатку в окремих найбільш «просунутих» людей, а в міру зміни умов життя поширюються подібно хвилям. Без внутрішнього спонукання людина легко застрягає в першому ж світі, що забезпечує їй мінімальний зовнішній комфорт, і може залишитися там назавжди. Так само одні 
й ті ж умови життя породжують різні картини світу, різні системи поведінкових стереотипів - залежно від особистого рівня розвитку людини.

На наш погляд, цікаво розглянути рівні спіральної динаміки з погляду того, як економічні механізми використовуються для побудови економічних систем на кожному рівні [732]. Перші шість рівнів розглядаються як «рівні існування», для яких характерне так зване мислення першого порядку (у т.ч. економічне). Потім відбувається «революційне зрушення» в індивідуальній і суспільній свідомості: з’являються рівні буття й мислення другого порядку з відповідною економічною еквівалентною.

Відштовхуючись від опису дев’яти хвиль буття К. Грейвза, можна простежити наступні соціально-економічні особливості кожного рівня в аспекті формування особистісної надійності суб’єктів підприємницької діяльності, що постає передумовою формування й функціонування соціального капіталу [733].

Бежевий колір - біовиживальний рівень. Для забезпечення й продовження життя формуються групи виживання. Основний і єдиний вид економічної ренти, що отримується на цьому рівні, - абсолютна рента від володіння природним ресурсом. Біовиживальний рівень буття і примітивне використання природних ресурсів (дешевих або відходів) спостерігається в основному на нижчих щаблях суспільної ієрархії в країнах, що розвиваються (пострадянські країни на початку 90-х років XX століття, балканські країни під час міжнаціональних конфліктів, Африка, Індія, окремі країни Близького Сходу, Азійсько-Тихоокеанського регіону тощо).

Фіолетовий колір - кровно-племінний рівень. Життя особистості в соціумі організується відповідно до принципів кровного й племінного споріднення. На цьому рівні з'являється й активно використовується механізм диференціальної ренти (в основному першого типу, пов'язаного 3 якістю ресурсу, що використовується) нарівні 3 абсолютною. Кланово-племінна боротьба відбувається за володіння більшою кількістю кращого ресурсу. Нарівні із природним ресурсом на перший план виходить людський (на рівні рабської або близької до рабської, кабальної, мало оплачуваної праці) і починає поступово 
проявлятися просторовий (регіональна рента). Спостерігається в багатьох країнах Азії, Африки, превалює в суспільних системах балканських держав, у багатьох пострадянських країнах на побутовому рівні.

Червоний колір - силовий рівень. Прояв окремої самості, відділеної від племені - могутньої, імпульсивної й героїчної - припускає силові методи захоплення ресурсу. Серед видів економічної ренти, як і раніше, превалює абсолютна рента, але різко зростає роль монопольної ренти на ресурс - через необмежені права феодала або іншого абсолютного господаря на розпорядження ресурсом - як природним, так і людським капіталом. Роль диференціальної ренти проявляється подвійно: 3 одного боку, йде боротьба за оволодіння кращим ресурсом (диференціальна рента першого типу), з іншого - власник поступово стає зацікавлений в охороні й поліпшенні ресурсу, що створює передумови для розвитку диференціальної ренти другого типу. Найбільш успішні володарі стають власниками казкових багатств за рахунок формування регіональної ренти (Іспанія часів конкістадорів, нацистська Німеччина), однак настільки ж швидко ці багатства втрачають через недосконалість механізмів конвертації ресурсів.

Синій колір - системно-ієрархічний рівень. У житті є зміст, напрям, мета і все це обумовлюється всемогутнім «Порядком», що визначає закони «правильного» i «неправильного» поводження, правила економічної гри. Найбільший інтерес цей рівень викликає з погляду використання всіх переваг економічної диференціальної ренти, що знаходить прояв у всіх видах ресурсів, які застосовуються для отримання доходу. На цьому рівні з'являються й розвиваються всі види ренти, що використовуються в сучасному світі: технологічна, інформаційна, фінансова, організаційно-управлінська, інноваційна, а також екологічна антирента. Особливу роль відіграє регіональна рента, що дає можливість окремим країнам і регіонам домінувати, ставати регіональними $\mathrm{i}$ світовими лідерами, уміло використовуючи територіальні переваги (Римська імперія, Британська імперія, США до Другої світової війни, Радянський Союз, пострадянська Росія, імператорська Японія, Бразилія, Індія, Китай кінця 90-х початку 2000-х років). 
Помаранчевий колір - рівень «вільного ринку». Цей рівень орієнтований на особистий успіх і кар'єру, що, в першу чергу, в США та розвинених країнах Заходу розуміється, насамперед, як отримання матеріальних благ. Рівень характеризується найширшим розвитком усіх видів ренти й рентних механізмів до ступеня високої досконалості. На перший план в умовах глобалізації виходять фінансова й інтелектуальна рента, регіональна рента стає одним із факторів геополітики, однак при цьому втрачається багато в чому іï первісний зміст як результат дії природно-ресурсних факторів. Роль регіонів, як акумуляторів ренти, визначається геоекономічними чинниками, належністю до певного макрорегіону, на які ділиться вся система світового економічного простору. Провідною стає роль екологічної антиренти, екстенсивна експлуатація природних ресурсів, заради досягнення стратегічної переваги, призводить до швидкої деградації природного середовища. Це соціально-економічні системи, що сформувалися після Другої світової війни у США, Західній Європі, після падіння СРСР - у Східній Європі й частково на пострадянському просторі (Україна, Прибалтика, Грузія) унаслідок застосування жорстких механізмів конкуренції i спроб повернення до використання переваг монопольної ренти, а також хижацької експлуатації природних ресурсів й забруднення навколишнього середовища, спричиняючи поляризацію суспільства й деградацію суспільних і державних інститутів при видимих економічних успіхах. Наслідком «помаранчевих» економічних процесів часто $є$ «перегрів» економіки. Результатом останнього багато в чому і стала перманентна іпотечна та банківська криза в США, яка переросла у 2008 році в глобальну рецесію світової економіки.

Зелений колір - екологічний рівень. Ідеали спільності, зв’язку між людьми, усвідомлення екологічних проблем, «мережеве» мислення створюють передумови для боротьби з монополізацією й абсолютизмом в економічних процесах. На перший план виступають нова екологічна й інтелектуальна рента, різко зростає роль диференціальної ренти другого типу. Власники унікальних ідей і технологій, які модернізують ідеї і поліпшують природні або інші ресурси, стають «новими володарями» світу (ідеї сталого розвитку, потужні мережеві 
компанії, корпорації, що діють у сфері інтернет-технологій, єдина Європа, розгалужені інфраструктурні центри на пострадянському просторі).

Роль регіональної ренти трансформується із природно-ресурсного й геоекономічного аспекту в новий - транзитний. Роль територій, як «воріт для пропуску ресурсів», стає важливішою, ніж роль «джерел ресурсів». Зростає значення технопарків і технополісів, вільних економічних зон. Суб'єктивне, нелінійне мислення висуває на перший план інтелектуальну ренту, роялті й людський капітал як джерело прибутку. Високоприбутковою індустрією стають спорт, відпочинок, навчання й медичне обслуговування. Однак обмеженість мислення першого порядку проявляється в явищі протистояння, витрачанні більших енергій на процес «боротьби з негативом», наприклад, із забруднювачами довкілля, з полюванням на диких тварин тощо. Сутність цього яскраво відображає фраза відомого суспільного діяча матері Терези про те, що на антивоєнних мітингах народжуються війни. Протиставити цьому можна інший, альтернативний підхід до цілісного використання всіх ресурсів розвитку індивіда й суспільства, заснований на інтеграції, - так зване «мислення другого порядку».

Буття і свідомість другого порядку, що мислить і намагається діяти в категоріях всієї спіралі буття, а не тільки категоріями будь-якого окремо взятого рівня, використовує всі відомі соціальні й економічні механізми. Це мислення поєднує в собі два рівні - жовтий колір (інтегративний) і бірюзовий колір холістичний (цілісний). На цих рівнях домінуючою є роль диференціальної ренти третього типу та інтелектуальної ренти. Окрім того, виникають, зароджуючись і розвиваючись, елементи нового економічного мислення, що орієнтується, перш за все, на духовне виробництво як основу для товарного виробництва. Можливою $є$ поява елементів духовно-економічної ренти i, так зване, духовне лідерство, духовне наставництво. Прикладом таких лідерів у політиці XX століття були М. Ганді, М.Л. Кінг та ін., які запропонували в системі певної духовної традиції (наприклад, гуманізму, рівноправ'я, національної чи расової свободи тощо) концепції соціально-економічного розвитку суспільства або країни в цілому. У XXI столітті лідерами в новому економічному мисленні стали всесвітньо відомі 
діячі Б. Гейтс, Б. Шеффер, Р. Гейдж, Р. Шарма, Б. Трейсі та ін. Їх ідеї об’єднують спрямованість на розвиток унікальних якостей фірми і працівника та максимальну віддачу в соціум від економічної діяльності, отримання прибутків за системою «зворотного зв’ язку» від власного внеску в економічну систему, в якій функціонує корпорація. Буття й парадигми свідомості другого порядку співвідносяться 3 подальшим удосконаленням ідей сталого розвитку та міждержавної співпраці в галузі охорони довкілля. Для таких економічних систем, поки сформованих на рівні окремих корпорацій (такою корпорацією вважається, зокрема, «Google»), деяких мережевих співтовариств характерне, з одного боку, сприйняття світу, природи та економіки як єдиного організму, а з іншого - орієнтація на цінність кожної людини - працівника і клієнта, клієнт-центрована робота. Компанії з таким мисленням широко використовують логістичний підхід, ведуть потужну добродійну діяльність, упроваджують технології особистісного зростання, коучингу в управлінні персоналом. Їм притаманна орієнтація на позитивний зворотний зв'язок і формування цілей з урахуванням інтересів індивідуума й системи в цілому. В оцінці персоналу таких компаній нарівні з поняттям IQ (інтелекту як міри інтелектуального капіталу) використовується поняття EQ (емоціонального інтелекту, запропонованого П. Саловеєм та Дж. Майером у 1990 році як міри соціального або духовного капіталу), за рахунок чого забезпечується реалізація інтелектуального потенціалу особистості в соціумі. Через наявність двох складових, що формують соціальний капітал - емоціональної та інтелектуальної, і відбувається формування та отримання інтелектуальної ренти.

Побудова економічної системи на парадигмі свідомості другого порядку в глобалізованому світі обумовлює виникнення нової духовності як альтернативи ортодоксальної духовної традиції. Така духовність містить у собі елементи всіх духовних традицій, трансперсональний рівень соціально-економічної взаємодії усередині глобальних систем уможливлює існування економічних систем поза народами, державами й расами, духовно-економічне лідерство в кризових ситуаціях стає важливішим за традиційне ресурсно-господарське лідерство. Мислення другого порядку досить вільно оперує традиційними поняттями 
«гарного» і «поганого», використовує системно-цілісні підходи до організації економічного процесу, інтегративне за своєю сутністю й активно використовує переваги всіх попередніх рівнів розвитку індивідуальної й суспільної свідомості та продуктивних сил у цілому [733, с. 98-101].

К. Грейвз виявив, що парадигми «рухаються зигзагом» між темами самовираження й самопожертви. Теплі кольори маркують парадигми самовираження (індивідуалістичні, матеріалістичні), а холодні - парадигми самопожертви (колективістські, ідеалістичні). Власне, саме тому він назвав свою теорію «спіральною», бо щоразу йде повернення до попереднього, але на більш високому рівні. Ще більш важливе в назві теорії слово «динаміка»- адже для людства воно означає характерний розвиток. Рух вгору завжди йде в бік ускладнення життя. Розширюється психологічний простір, широта погляду на світ, росте число «ступенів свободи» і граней особистості, різноманітність альтернативних способів зробити щось, ускладнюються потреби людини.

Особистісна надійність - це здатність людини контролювати, захищати й розбудовувати свій психологічний простір. Тому особистісна надійність базується на узагальненому досвіді успішної автономної поведінки. Вона являє собою форму суб'єктності людини й дає змогу в різних формах спонтанної активності реалізувати їі потреби. Надійність має прояв у переживанні власної самості й авторства власного буття (упевненості особистості в тому, що вона діє згідно 3 власними бажаннями й переконаннями), відчутті своєї доречності у просторовотимчасових і ціннісних обставинах свого життя, які вона створює або приймає. Особистісна надійність є цілісною функцією і як процес, і як стан збалансованості, гомеостатичності організуючих рівнів. Рівень психічного розвитку особистості, особливості онтогенезу, рівень розвитку соціальних навичок, культури й свідомості мають самостійне значення для ефективності процесів адаптації, становлення особистісної надійності. Ці рівні також значимі для здатності особистості до самоадаптації [734].

Ненадійність характеризується переживанням особистісної нестабільності й підпорядкованості, відчуженості, фрагментарності власного життя й 
характеризується труднощами в пошуку об’єктів середовища, з якими особа себе ідентифікує, відчуваючи себе «на чужій території» і не у своєму часі. Особистісна надійність являє собою еволюційно й соціально усталену системну якість особистості, що є необхідною умовою її нормального функціонування й розвитку. Виокремлено такі рівні досліджуваної якості, як наднадійність, нормальна (помірна) надійність, ненадійність і розбалансованість.

На відміну від традиційного уявлення про прояви самостійності й незалежності, які залишалися усередині інтрапсихічної парадигми, І.О. Котик розглядає особистісну надійність як стан меж психологічного простору [735]. Психологічний простір особистості - це суб’єктивно значущий фрагмент буття, що визначає актуальну діяльність і стиль життя особистості, включаючи комплекс фізичних, соціальних і психологічних явищ, з якими особистість себе ототожнює. Особистісна надійність викарбовується станом меж психологічних (ціннісносмислових, мотиваційних, когнітивних, емоційно-вольових і поведінкових) позначок, що відокремлюють сферу психологічного простору особистості. Межі зумовлюють ідентичність людини, презентують інструмент рівноправної взаємодії й вибору зовнішніх впливів, позначають границі особистої відповідальності, визначають специфіку особистісної надійності. Як порушення, так і підтримка меж закріплюються в «Я-концепції» і виражаються в об’єктивній поведінці людини [736].

Особистісна надійність людини - динамічне явище; одиницею виміру надійності є психологічна ситуація, яка вирішується за допомогою психологічних захистів і психологічного опанування. Активні способи опановуючої поведінки поєднуються з досягненням особистісної надійності, а пасивні - ненадійності. Фрустрація прагнення до надійності, певним чином, психологічного простору через символічний характер останнього, призводить або до заміщення цього виміру іншим, або до зниження рівня надійності (ненадійність), або його надмірного посилення (наднадійність). Такі порушення, як ненадійність i наднадійність, можуть компенсуватись у процесі життєдіяльності або цілеспрямованого розвивального впливу, що полягає, відповідно, в посиленні 
особистого контролю над різними сферами буття або у визнанні соціальних та особистісних меж іншої людини як цінності [737, с. 26-31].

Отже, особистісна надійність - це складне, динамічне явище; це здатність людини контролювати, захищати й розбудовувати свій психологічний простір; це те, що архіважливо у підприємницькій діяльності, яка вимагає високий гатунок відповідальності за все виробництво та його інфраструктуру.

Відомо, що джерелом усякого руху є єдність і боротьба протилежностей. Породжуючи протиріччя як у самому предметі, речі, так і в їх взаєминах із зовнішнім середовищем, вони розв’язують їх і спонукають предмет чи річ до руху. Проте не кожен рух слід уважати розвитком і не кожне розв’язання протиріч може стати джерелом цього розвитку. Наукова практика свідчить, що рушійною силою розвитку, його джерелом стають лише ті протиріччя, які об'єктивно й безпосередньо пов'язані із сутністю самого предмета, речі чи процесу. Протиріччя, що є первісними моментами в бутті цих речей, такий розвиток не зумовлюють. Тільки протиріччя сутності породжують розвиток якості.

В контексті особистої надійності суб'єкта підприємницької діяльності означене положення дозволяє припустити, що джерелом розвитку цих властивостей вважається заперечення між можливостями, уподобаннями, цінностями особистості, які вона втілює в життя в обраній діяльності, й зовнішніми, соціальними життєвими обставинами, які визначають вимоги до даної діяльності та місце їі втілення. Це логічно, тому що кожна сутність виявляє себе лише крізь своє існування або ж спосіб буття. Особистісна надійність підприємця оцінюється тільки в тій мірі, в якій враховуються умови, при яких здійснюється підприємницька діяльність.

На відміну від сутності, що породжена протиріччями всередині самої речі, ii iснування обумовлене протиріччями серед різноманітних речей. Існування особистісної надійності суб’єкта підприємницької діяльності як буття речі, іiі якісне визначення, яке було взяте з боку власного зовнішнього опосередкування або детермінації, котра передбачає, що вона обгрунтована суспільною значущістю, потребує затребуваність у суспільстві. Без даної затребуваності 
якість надійності особистості втрачає значення власного існування, що призводить до іï руйнування. Пояснюється це тим, що будь-яка конфігурація переміщення матерії вважається одночасно сутністю й існуванням. Внаслідок цього вона підпорядкована двом типам протиріч - внутрішнім і зовнішнім. Якшо у разі річ співвіднесена не лише сама з собою, але і з усілякими іншими речами, то вона неминуче потрапляє під їх вплив, опосередковується між ними, що власне і призводить до протиріччя самого прецеденту та до їх існування.

Сутність особистісної надійності суб’єкта підприємницької діяльності не виявляється без потреби свого існування, одного не може бути без іншого. При цьому вони органічно пов’язані 3 якостями особистості, їх визначеністю й цілісністю. Вони представляють різні аспекти механізму породження надійності як якості особистості, що ідеально представлені в плані внутрішньої й зовнішньої взаємодії.

Повнота науково-теоретичного осмислення феномена особистісної надійності не може бути обмежена означеними категоріями. Вони утворюють початкові орієнтири, що задають онтологічну картину досліджуваного об'єкта й загальні гносеологічні принципи його вивчення. Означені категорії, з одного боку, дозволяють з’ясувати ті прогалини у змісті науково-педагогічного знання, наповнення яких сприятиме розробці загальної теорії надійності та концепцій іiі становлення. 3 іншого боку, вони створюють необхідне підгрунтя для аналізу особистісної надійності суб'єкта підприємницької діяльності на рівні його безпосереднього буття.

Сутність особистісної надійності суб’єкта підприємницької діяльності, як системного явища, може бути розкрита під час полісистемного аналізу, який передбачає розгляд явища з різних боків, у рамках різних систем, на різних рівнях. Можна виділити кілька рівнів аналізу особистісної надійності суб’єкта підприємницької діяльності.

Перший, провідний, рівень - теоретико-методологічний аналіз особистісної надійності суб’єкта підприємницької діяльності як психологічної категорії: вивчення історії розвитку ідей надійності; характеристика підприємницької праці 
3 позиції надійності; визначення галузі наукового знання про особистісну надійність суб’єкта підприємницької діяльності; розробка структури й понятійного апарату концепції особистісної надійності суб'єкта підприємницької діяльності. Встановлено, що особистісна надійність виступає динамічною системою, яка розвивається у процесі діяльності підприємців. Складність і різноманіття зв’язків особистості у фаховій діяльності робить систему особистісно-діяльнісних взаємин підприємців досить динамічною, що проявляється у розвитку компонентів психологічної структури особистісної надійності. Теоретичний аналіз концепції та наукових підходів до розвитку особистісної надійності підприємців і підвищення їх професіоналізму дозволило обгрунтувати психологічну структуру особистісної надійності фахівців підприємницької діяльності і визначити основні теоретико-методологічні підходи (системності, гуманістичності, діяльності, інтегральної суб’єктності, детермінізму, компетентності) та принципи (індивідуальності, спільності, співдружності, організації, вибору, балансу цінностей, професійного розвитку), що зумовили добір методів та заходів вивчення компонентів і змісту цієї структури (рис. 1).

Домінуючою ідеєю усього навчального процесу проходить ідея, що змістовна модель особистісної надійності суб’єктів підприємницької діяльності інтегрує в собі концепти професіоналізму (підприємливість як наскрізна компетентність, професійна роль та функції, загальні здібності до підприємницької діяльності), суб’єктності (рівні світогляду, соціальноекономічна активність), особистісної культури (психологічна, комунікативна, інноваційна, правова, організаційна та корпоративна), психофізіологічні, професійні та особистісні якості.

Другий рівень - феноменологічний аналіз особистісної надійності суб’єкта підприємницької діяльності як психологічного явища, яке пізнається шляхом опису підприємницької діяльності: нормування особистісної надійності підприємця; диференціація перешкод у професійній праці підприємця; класифікація порушень особистісної надійності суб’єкта підприємницької 
діяльності; типологія детермінант особистісної надійності суб’єкта підприємницької діяльності; типологія особистісної надійності суб’єкта підприємницької діяльності.

Результатом вивчення особистісної надійності суб’єкта підприємницької діяльності на перших двох рівнях $є$ iï функціональний аналіз 3 точки зору внутрішньої організації й механізмів функціонування (визначення критеріїв і показників оцінки особистісної надійності суб’єктів підприємницької діяльності).

Третій рівень передбачає генетичний аналіз особистісної надійності суб’єкта підприємницької діяльності з позиції категорії розвитку: опис змісту, етапів, закономірностей системогенезу особистісної надійності підприємця; розроблення моделі та програми розвитку особистісної надійності суб'єктів підприємницької діяльності.

Результатом вивчення особистісної надійності суб’єкта підприємницької діяльності на третьому рівні виступила розробка моделі розвитку мотиваційного, когнітивного, поведінкового, ціннісно-смислового, емоційно-вольового компонентів, які впливають на розвиток особистісної надійності суб'єктів підприємницької діяльності, що відображає: принципи розвитку особистісної надійності фахівця; змістові компоненти особистісної надійності; професійні функції (ролі); програму розвитку особистісної надійності; форми, методи та засоби розвитку особистісної надійності; моніторинг психологічної ефективності програми з розвитку особистісної надійності; рівні та критерії сформованості особистісної надійності суб'єктів підприємницької діяльності (показники змістовних компонентів особистісної надійності: ціннісно-смисловий; мотиваційний; поведінковий; емоційно-вольовий; когнітивний). Кожен 3 перерахованих рівнів аналізу особистісної надійності суб'єктів підприємницької діяльності має свою специфіку, в той же час вони в тій чи іншій мірі перетинаються між собою, не вичерпуючи один одного. Це дозволяє виявити всю багатоплановість і багатовимірність особистісної надійності суб'єктів підприємницької діяльності як реального психологічного явища [738]. 


\section{ПРОФЕСІОНАЛІЗМ:}

- підприємливість як наскрізна компетентність (узяття на себе ініціативи, планування та управління, робота 3 неоднозначністю, невизначеністю та ризиками, співпраця 3 іншими особами, навчання через досвід у процесі діяльності; самосвідомість і самоефективність, фінансова та економічна грамотність, виявлення можливостей, прогнозування);

- професійна роль (функції): «новатор-підприємець» (інноваційна); «господарник-виробник результатів» (економічна, ризикова); «керівник-адміністратор» (управлінська); «лідерінтегратор» (соціальна, ресурсна);

- загальні здібності до підприємницької діяльності (потреба в досягненнях, потреба в незалежності/автономії, схильність до творчості, уміння йти на розумний (зважений) ризик, цілеспрямдваність та рішучість

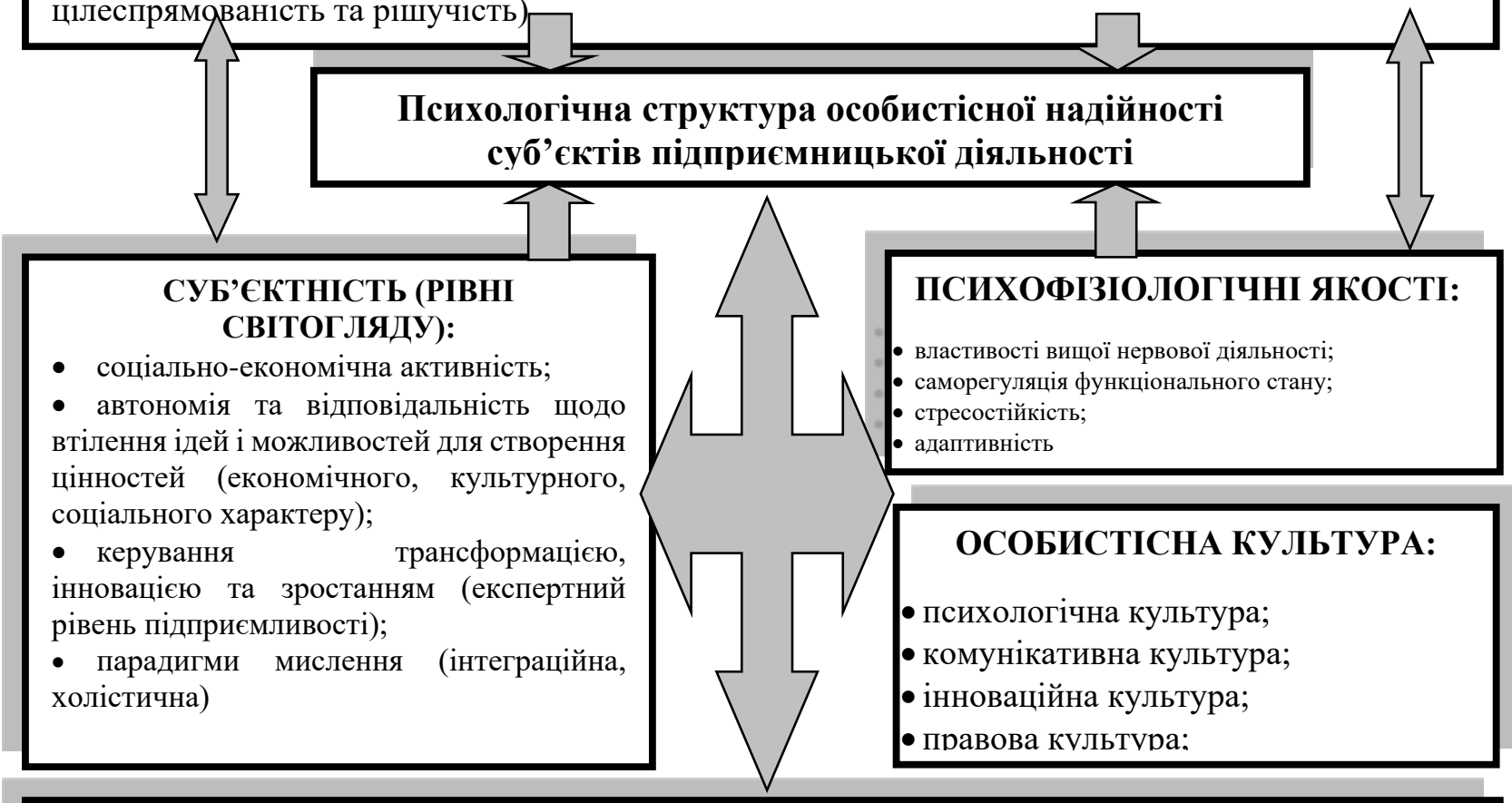

\section{ПРОФЕСІЙНІ ТА ОСОБИСТІСНІ ЯКОСТІ:}

морально-правові цінності, сенсожиттєві орієнтації, показники самоактуалізації (ціннісно-смисловий компонент);

- мотиваційні тенденції, тип спрямованості, потреба в: досягненнях, подальшому розвитку, автономії (мотиваційний компонент);

- особливості пізнавальних процесів та інтелектуальних якостей, рівень професійних знань та компетентностей, соціальний інтелект (когнітивний компонент);

- емоційна зрілість, стійкість до емоційного вигорання, емоційний інтелект (емоційно-вольовий компонент);

модель подолання стресових ситуацій, тип реакцій на дію стресорів (поведінковий компонент).

\section{Рис. 1. Змістовна модель особистісної надійності суб'єктів підприємницької} діяльності

Таким чином, концепція особистісної надійності суб’єктів підприємницької діяльності - це напрям наукового психологічного знання, що дає цілісне уявлення про структуру, функції, детермінанти, закономірності та суттєві зв’язки особистісної надійності підприємця. 
Сучасний стан України потребує професіоналів, які активно здійснюють свій внесок у розвиток економіки суспільства. Провідну роль у цьому аспекті відіграють фахівці підприємницької діяльності, які можуть упроваджувати в практику сучасної економіки нові наукові дослідження через свій професіоналізм та особистісну надійність. У значних наукових напрацюваннях учених звернуто увагу на те, що аспектом пильного розгляду сьогодні $\epsilon$ психологічні особливості структури особистісної надійності та професіоналізму підприємців і їхня роль у продуктивній професійній діяльності на благо України.

Надійність підприємців розглядається як інтегральна якість особистості, яка може впливати на професійну активність фахівця незалежно від складних умов праці. Надійність підприємця проявляється у професійній діяльності й формує стійкий стан об'єктивної та суб'єктивної здатності до співпраці та підвищення іiі ефективності. Дослідник В.А. Криволапчук [739] у структурі психологічної надійності виділяє наступні компоненти: мотиваційні, когнітивні, емоційно-вольові, поведінкові, які впливають на розвиток та реалізацію професійної надійності підприємців. Автор звертає увагу на те, що особистісна надійність лежить в основі формування здібностей ефективно виконувати професійну діяльність у складних умовах трудового процесу. Це підтверджує у своїх дослідженнях В.А. Крутецький [740].

На думку 3.Р. Кісіль [741], накопичені сучасною теорією і практикою психологічної науки теоретичні й емпіричні дослідження можуть слугувати відправним пунктом для використання інтегрального підходу до розробки професіоналізму фахівців підприємницької діяльності. Важливе значення автор надає проблемі самоконтролю, самореалізації й надійності підприємців у професійній діяльності.

У системі особливостей професійної діяльності фахівців С.О. Климов [742] висвітлює проблеми самовизначення, самовідношення та їх адаптаційних можливостей. Дослідник В.О. Толочек [743] вивчає проблеми ризику і стилю професійної діяльності фахівців та їх професійне довголіття. 
Успішне виконання професійної діяльності підприємцями пов'язане 3 внутрішнім і зовнішнім професійним потенціалом особистості, який допомагає суб'єктам підприємницької діяльності реалізувати себе в складних, нестандартних умовах та екстремальних ситуаціях. Накопичений внутрішній потенціал підприємець використовує для отримання успішного результату в професійній діяльності. Сучасні теоретичні розробки дають можливість виявити головні напрями дослідження проблеми надійності суб’єктів підприємницької діяльності.

Значним внеском $є$ роботи науковців, які зосереджують увагу на розробці концептуальних підходів до вивчення психології надійності та професіоналізму суб’єктів підприємницької діяльності. Як зазначає 3.Р. Кісіль [741], теоретичну основу психологічних концепцій дослідження фахівців у професійній діяльності складають наступні підходи: - концепџія діяльності, як цілеспрямованої відкритої системи і людини як суб’єкта діяльності, що реалізує й розвиває свій професійний потенціал; - концепиія інформащійних і конщептуальних підходів; трансформаційна теорія навчання та концепція впливу екстремальних умов; кониепиія забезпечення професійної надійності людини; - концепції вимог до властивостей людини-професіонала, професійного відбору, тренажерної підготовки і спеціальної реабілітації людей після напруженої й небезпечної професійної діяльності; - конщепція збереження здоров'я $i$ професійного довголіття; - концепиія проектування діяльності. На думку автора, ці виділені теоретичні підходи вивчення психології надійності підприємців у професійній діяльності дозволяють через арсенал концепцій, категорій, методик та методів отримати широкий спектр результатів досліджень. Він висловлює положення, що провідними методологічними принципами дослідження надійності можуть бути: техніко-економічна, природничо-наукова, культурно-історична парадигми, що дозволяють поєднувати гуманістичні цінності 3 якіснопрофесійними моделями фахової діяльності особистості. У цих дослідженнях системно-утворюючим принципом є професійна спрямованість і особистісна 
надійність, які є основою формування професійної успішності та розвивають особистий потенціал підприємців.

Цілісне розкриття феномена психологічної надійності суб’єктів підприємницької діяльності науковці здійснюють з урахуванням як позитивних, так і негативних якостей, що впливають на особистість професіонала. Важливе значення в підвищенні працездатності підприємців має мотивація на успіх у виконанні професійної діяльності. На розвиток надійності підприємця активно впливає його «Я-концепція», яка розглядається як система уявлень фахівця про себе, своє ставлення до успіху та невдач у професійній діяльності. Розвиток «Яконцепції» професіонала пов’язаний з формуванням соціально-психологічного самопочуття підприємця, як емоційно-ціннісного ставлення до себе, до діяльності, і це $\epsilon$ інтегральною характеристикою збалансованості й гармонійності внутрішнього світу суб’ єктів підприємницької діяльності [735].

Науковець М.А. Ажажа [744] описує основні положення вивчення шляхів корекції особистісних якостей менеджера-професіонала i презентує їх наступних теоріях: 1) теорія рис - обгрунтовує особистісні якості, які необхідні фахівцю для успішної професійної діяльності; 2) факторний підхід - передбачає аналіз окремих чинників, які впливають на розвиток професійної надійності різних досліджуваних груп; 3) ситуащійна теорія - стверджує, що лідерство є продуктом ситуації групового життя, в яких виокремлюють осіб, що мають перевагу над іншими і керують ними у професійній діяльності. Це формує у лідера стійкий стан, котрий забезпечує об’єктивну і суб’єктивну здатність до співпраці й ефективної діяльності; 4) париุіальна концุепцุiя - передбачає дослідження й корекцію особистісних способів та методів орієнтації підприємців у соціальному середовищі, спрямовану на зміну поведінки та самооцінки; 5) системний підхід - полягає у вивченні досліджуваного феномена як цілісної системи, в якій сукупність окремих компонентів у взаємодії дає змогу виявити нові якості особистості, що забезпечують ефективне функціонування всієї системи; 6) поведінковий niдxid - означає, що підприємець володіє формами поведінки, необхідними в соціумі та для групи, якою він керує. 
Таким чином, сучасні дослідження особистісної надійності підприємців 3 позиції різних теорій, концепцій та підходів доповнюють систему знань про іiі психологічні особливості, що дозволяє впливати на їі розвиток у підприємця 3 метою його ефективної професійної діяльності. Наукові пошуки молодої незалежної України, в умовах демократизації суспільства, потребують ураховувати зміни в особистості щодо нових умовах буття та професійної діяльності. Сучасний підприємець повинен не тільки адаптуватися до нової суспільної реальності в Україні, але й бути, зокрема, активним, ініціативним та ефективним у своїй професійній діяльності. Теоретичний та практичний досвід науки служить основою для розробки інтегрального підходу до вивчення особистісної надійності суб'єктів підприємницької діяльності.

О.В. Кобець [745], вивчаючи професійну діяльність фахівців, зосередив увагу на принципові професіоналізму, який, на його думку, передбачає комплексне вивчення професіонала, його властивостей, професійного стану у фаховій діяльності. Розглядаючи проблему професіоналізму фахівця, він стверджує, що його стан, як професіонала, характеризується внутрішньо й зовнішньо. Характеристика професіоналізму, як системи, описується автором на основі функціонального, морфологічного та емоційного підходів. Професіоналізм, як об'єкт вивчення, викликає інтерес до того, яке місце він посідає серед інших психологічних явищ суб'єкта фахової діяльності. Враховуючи ці підходи, професіоналізм фахівця треба вивчати, починаючи 3 опису його функцій і критеріїв. Розглядаючи професійні функції фахівців, варто звернути увагу на те, що ці функції вивчаються з урахуванням обов'язків, які виконує фахівець у професійній діяльності, а також кола тих завдань, які необхідно йому вирішувати. Розроблені автором критерії професіоналізму дозволяють мати уявлення про сутність виконання узагальнених і конкретних функцій об’єкта, що вивчається 3 процесуального напряму. Функції професіоналізму спрямовані на якісне перетворення суб'єкта діяльності й орієнтовані на ефективне виконання професійних завдань: - створення таких професійних умов, за яких продуктивність і якість праці будуть знаходитись не 
нижче нормативного рівня; - збереження нормативно схваленого способу конкретного професійного напряму на основі індивідуальних якостей; - розвиток надійності професіоналів та спільноти, що $є$ частиною професійного співтовариства, учасником якого є фахівець.

У загальному випадку виконання професійних функцій підприємцем супроводжується отриманням не тільки нормативних результатів підприємницької діяльності, але й певних витрат, які можуть бути як матеріально-економічними, так і соціально-психологічними. Такі підходи потребують вивчення умов розвитку психологічної надійності суб’єктів підприємницької діяльності для підвищення їхнього професіоналізму та ефективності праці [739].

Інтенсивність психологічного аналізу феномена «надійність» у конкретній галузі соціального буття надає можливості внести своєчасні корективи та покращити етико-емоційний стан у суспільстві. Такі дослідження дають поглиблений аналіз суті та значущості надійності як феномена взаємодії та довіри в суспільстві [746]. Дослідження надійності сприяє систематизації знання про розуміння надійності та іiі значущості в національному й культурному просторі України. На основі огляду різних теоретичних досліджень та методологічних практик утвердилась думка про те, що надійність є ключовою категорією для конструювання моделей суспільного життя, що потребує іiі присутності в людських взаєминах як на благо особистості, так і на благо розвитку українського суспільства [747].

Соціально-особистісна надійність $є$ провідним, системотворчим чинником, що окреслює цілі, характер, емоційно-психологічну спрямованість майбутнього фахівця на процес і результати навчально-професійної діяльності, зумовлює рівень функціонування всієї системи професійної надійності загалом. У соціально-особистісній надійності унаочнено провідні потреби, мотиви, ціннісні установки та спрямованість майбутніх фахівців на професійну діяльність. 
У структурі соціально-особистісної надійності відображено такі загальнолюдські якості, як гуманізм, відповідальність, емпатія, почуття обов'язку, прагнення прийти на допомогу, колективізм, товариськість тощо [748].

Аналіз рефлексії надійності суб’єктів підприємницької діяльності у соціокультурному дискурсі України показав інтерес науковців до цієї проблеми і спробу ввести її в національний науковий дискурс. Науковий аналіз надійності дає змогу залучати цей феномен до раціонального дискурсу ціннісних трансформацій українського суспільства. Особистісна надійність стала предметом наукової дискусії, що дозволило корелювати ії з такими практиками як економіка, соціологія, державне управління, психологія у наступному сенсі: причини ï кризи; - потреби iï обгрунтування у відповідному українському соціумі; - прогнозування механізмів підвищення рівня надійності суб'єктів економічної діяльності в суспільстві [749].

До переліку найбільш значущих проблем підприємців потрапили такі, як: - неефективність психолого-економічної взаємодї; - неефективність організащійно-управлінських засобів; - ціннісно-інституційна деградація важливих сегментів фінансового ринку; - причини глобальної економічної кризи; - зміна логіки функиіонування взаємин у боротьбі з корупиією [750].

Потреба у вирішенні актуальних питань надійності суб'єктів підприємницької діяльності стає умовою оздоровлення економіки і іiі здатності консолідувати суспільство у розв'язанні проблем його розвитку. В економічній підприємницькій діяльності надійність розглядається як компонент ціннісної основи раціонального вибору діяльності, прийняття рішень в умовах суперечливої інформації, оптимізації результатів господарювання. Надійність у підприємницькій діяльності зменшує трансактивні витрати за умов налагодження взаємин контрольно-перевірочної діяльності партнерів і самоконтролю.

Таким чином, особистісна надійність формує відчуття взаємної довіри, що створює ситуацію ефективних взаємин у підприємницькій діяльності. Подолання 
соціально-економічних негараздів в українському суспільстві не може відбутися без високорозвиненої надійності фахівців господарської діяльності. Відродження надійності в підприємців та у суспільстві взагалі є запорукою поглиблення демократизації співпраці як норми буття, що позитивно впливає на рівень ділової активності, успішної професійної діяльності, підвищення емоційного самопочуття, покращуючи виробництво і його обсяг. Особливий акцент у сучасних дослідженнях надійності робиться на тому, що вона сприяє соціальній інтеграції та підтримує інновації в економічному розвиткові країни. У той же час механізмом збереження надійності вважається відкритий, толерантний, чесний діалог у комунікативній системі суб’єктів підприємницької діяльності. На думку дослідників, надійність фахівців відіграє провідну роль у мінімізації рівня корупції в суспільстві і створює умови для прозорості, відкритості, чесної конкурентоспроможності в розбудові економіки.

Із вищевикладеного для нашого дослідження ми виділяємо наступні теоретико-методологічні принципи та концепції:

1. Принциип професійного розвитку особистості. Він потребує вирішення зовнішніх і внутрішніх протиріч суб'єктів підприємницької діяльності. Ці протиріччя можуть виникати між інтересами і спрямованістю фахівців та їх професійними можливостями. Професійне становлення фахівця потребує збагачення його внутрішніх ресурсів, що пов’язано з перетворенням особистісних якостей, його індивідуального потенціалу [751]. У фаховій діяльності підприємців відбуваються різні моделі професійної свідомості, що допомагає вирішувати складні професійні завдання. На цій підставі розвиток професійної надійності спонукає до підвищення ефективності праці.

2. Принu̧ип організаціï. Показує, що особистість організує свій досвід i свої якості, які мають індивідуальні відмінності та утворюють систему, відмінну від інших суб'єктів діяльності, а також функціонують у цій системі, долаючи життєві труднощі. Особистісна надійність розширює індивідуальні можливості підприємців в організації професійної діяльності. 
3. Принцип вибору. Свідчить, що особистість розвивається в напрямі корисному для себе або для соціуму. Для особистості використання одних якостей може бути пріоритетними над іншими, що дає змогу ефективно розвивати свій бізнес. Оскільки професійні стосунки в підприємницькій діяльності не є постійними, то це обумовлює організаційні зміни з формуванням нової системи взаємодії.

4. Принциип індивідуальності. Вказує, що кожна людина створює коло своєї професійної діяльності на основі унікальної системи особистісних якостей, що відкриває можливості для активної діяльності в підприємницькій сфері. Проявляючи надійність, кожний підприємець підвищує індивідуальний авторитет серед своїх колег-фахівців.

5. Принции спільності. Підкреслює, що підприємці мають широке коло взаємодії, але спілкуються більше 3 тими, до яких $є$ професійний або особистісний інтерес та які мають надійний досвід або одну культуру взаємодії.

6. Принции співдружності. Наголошує, що для продуктивної взаємодії в підприємницькій діяльності необхідно, щоб партнери правильно інтерпретували взаємні дії, забезпечуючи позитивний результат. Успішна соціальна взаємодія дає бажаний ефект, коли партнери мають взаємне розуміння та погляди на життя, соціальні прогнози й підтримуються іншими.

7. Принции конкуренції. Презентує те, що в професійній діяльності у підприємців є бажання знайти краще соціальне середовище для збільшення прибутку або кращого вирішення фахових питань. Зіткнення різних поглядів суб'єктів і груп у мікро- і макросередовищі посилює конкуренцію й потребує від підприємців уміння не тільки вистояти, а й підвищити свою конкурентоздатність. На міжособистісному, міжгруповому й мікросоціальному рівнях можуть відбуватися як негативні, так і позитивні наслідки конкуренції. Найбільш успішні й конкурентностійкі ті фахівці, які мають високорозвинену професійну надійність.

8. Принциип балансу изінностей. Означає визнання в суб'єктів різних підходів, гіпотез, протилежних стратегій, особистісних та суспільних цінностей, 
які пропонуються партнерами або різними групами взаємодії. Такий стан може як розвивати, так і негативно впливати на розвиток підприємницької діяльності, знижувати успіхи та змінювати цінності міжособистісної та соціальної взаємодії. Високорозвинена професійна надійність допомагає підприємцям збалансовувати цінності взаємодії у професійній діяльності.

9. Принц̧ип пульсаціiі. Показує, що особистісна система суб’єктів підприємницької діяльності має не тільки постійний розвиток цієї системи, але й періодичних ціннісних їі змін. Це обумовлює проявлення особистістю різних своїх станів як глибинних, так і поверхневих, і створює умови приписування певних рис партнерам по взаємодії, підтримку звичних смислових стратегій, зняття суперечностей. Усе це вимагає активно розвивати особистість підприємця й підвищувати його надійність.

10. Принu̧ип dianaзону. Звертає увагу на те, що підприємці, які мають набір об’єктивних та суб'єктивних якостей, плідно працюють і взаємодіють 3 такими партнерами, які найбільш надійні. Це дозволяє суб’єкту підприємницької діяльності успішно працювати, розширювати діапазон взаємодії й мати підтримку партнерів.

11. Інформаційний принщ̧ип. Дозволяє виявити динаміку розвитку підприємства, вибрати найбільш надійних та успішних підприємців, як партнерів, і мати інформацію про загальний стан розвитку підприємницької діяльності в регіоні та суспільстві. Прогнозування надійності, виконання професійних завдань вимагає виділяти основні принципи іiі побудови. Такий підхід прогнозування надійності для успішної діяльності фахівців дозволяє передбачити тенденції їі розвитку й хід процесів у професійній діяльності.

Слід звернути особливу увагу у навчальному процесі на аналіз існуючих підходів, щодо складання прогнозів, який дозволив виділити наступні їхні види: 1) основні типи: - нормативні (визначення напрямів і термінів досягнення); пошукові (можливих станів, явищ у майбутньому); 2) періоди попередження: оперативні; - короткострокові; - середньострокові; - довгострокові; - не довгострокові. Прогнозування успішної професійної діяльності підприємців є 
найбільш актуальними за довгостроковими прогнозами. Дослідники виділяють наступні параметри прогнозу: - термін попередження або глибина прогнозу; період прогнозу, що будує ретроспекцію; - прогнозний горизонт - це період встановлення точності прогнозу; - точність прогнозу - визначається оцінкою довільного інтервалу прогнозу; - вірогідність прогнозу - це прогноз у заданому інтервалі; - надійність прогнозу - стійкість, статичність прогнозованого явища [752].

При розробці прогнозу надійності професійної діяльності підприємців необхідно отримати інформацію про особливості психологічного складу фахівців через бесіди, спостереження, експертні оцінки. Отримана оцінка часто має описовий характер про особистість, її кваліфікацію, їі поведінку. На практиці використання психологічних методик дозволило активно досліджувати надійність фахівців. Високий рівень сформованості інтелектуальної діяльності фахівця складається із стійкості таких психологічних характеристик, як повнота та точність інформації, готовність до її оперативного використання. Незважаючи на значну кількість спеціальної інформації, відмічається ускладнення процедури прогнозування професійної надійності особистості, що вимагає всебічного об’єктивного вивчення професійно важливих якостей підприємців [750].

У ролі важливого компонента професійної надійності виступає емоційновольова стійкість, як здатність виконувати професійні завдання в умовах емоційного впливу, шляхом співставлення результатів діяльності. Принципово важливим є положення використання психічних моделей емоційних ситуацій, в основі яких покладені специфічні емоційні чинники, характерні для діяльності підприємців. Важливість прогностики в діяльності підприємців є очевидною, бо складання прогнозів надійності допомагає покращити професійну діяльність фахівців [749].

Теоретико-методологічну основу дослідження феномена особистісної надійності суб’єктів підприємницької діяльності склали системний підхід у психології. Це означає, що особистісна надійність підприємця може бути відображена як складна багаторівнева система, набір компонентів якої 
визначається їхніми регуляторними функціями у вигляді структурнофункціональної моделі.

Ряд дослідників вивчають механізми регуляції надійності діяльності особистості на різних рівнях іï буття: біологічного, психологічного та соціального. Так, до біологічного рівня зараховують як генетичні, так i фізіологічні регуляторні механізми забезпечення надійності людини, іiї стійкого і стабільного пристосування до довкілля, гомеостатичної й адаптивної регуляції процесів забезпечення ii життя й діяльності в нормальних і екстремальних умовах.

Психологічний рівень забезпечення надійності підприємців полягає у визначені ролі деяких психологічних феноменів у формуванні й прояві надійності - індивідуальні, що стосуються конкретного суб'єкта та їх проявів у забезпеченні активації результативних процесів роботи, покриття недостатнього розвитку деяких процесів, мобілізації операціональних функцій, реалізації планів і стратегій поведінки [753, с. 80].

Соціальний рівень регуляції надійності підприємців відображає особливості спільної діяльності, міжособистісних стосунків і групових процесів у трудовому колективі [738]. Психологічний клімат, сумісність і згуртованість членів групи, стиль керівництва, конфлікти, лідерство та інші соціальнопсихологічні феномени визначають рівень професійної придатності колективного суб'єкта діяльності й залежать від ряду індивідуальнопсихологічних особливостей членів групи та відбиваються на рівні особистої і групової надійності [754, с. 253-254].

Вищою формою регуляції діяльності суб'єкта виступають смисли та ідеали. Тим самим феномен готовності може бути результатом взаємодії смислообразів, суб’єктно-орієнтованих мислення образів та емоційно-вольової цілеспрямованості особистості. У цьому контексті виконують функції спонукання й підтримки в необхідному для вирішення завдань діяльності стану психіки людини, але при цьому не можуть повністю визначати ідейно-смислове завантаження активності суб’єкта [755, с. 19-20]. 
Виокремлення рівнів вивчення особистісної надійності грунтується на ідеї багаторівневої психологічної організації особистості й отримало осмислення в роботах дослідників Б.Г. Ананьєва [756], Б.Ф. Ломова [757], Н.Ф. Шевченко [758], згідно яких людина - це біосоціальна істота, наділена свідомістю і здатністю до діяльності. Відповідно до неї надійність можна розглядати на індивідному, суб'єктному та соціальному рівнях. Індивідний рівень передбачає врахування вікових, статевих, конституціональних особливостей, нейродинамічних властивостей, динаміки психофізіологічних функцій, особливостей темпераменту фахівця.

Розгляд надійності на суб'єктному рівні стає можливим за допомогою використання уявлень про суб'єктність людини як складної психічної якості, що об’єднує різні рівні прояву активного, ініціативного, інтеграційного, системного початків. Розуміння суб'єктності у психології пов'язане з тлумаченням суті даного поняття як перетворення людини на суб'єкт власної життєдіяльності і як особливий рівень розвитку її самосвідомості.

На соціальному рівні об’єктом дослідження є стійка система соціально значущих рис, які особа виробляє у процесі соціалізації й засвоєння соціокультурного досвіду та реалізує у процесі соціальних зв'язків через активну предметну діяльність та спілкування.

Кожний рівень надійності пов'язаний зі всіма іншими, залежить від них і системи в цілому. Системний підхід дозволяє розглядати особистісну надійність підприємців як складне утворення, що має ієрархічну будову, в якій виділяються компоненти (структурні та змістові), функції та критерії оцінювання (рис. 2).

Системність надійності суб'єктів підприємницької діяльності визначає можливість відображення іiї як багаторівневої системи, що складається з трьох структурних компонентів, виділених відповідно до трьох рівнів ії вивчення суб'єктна, діяльнісна та функціональна надійність. 


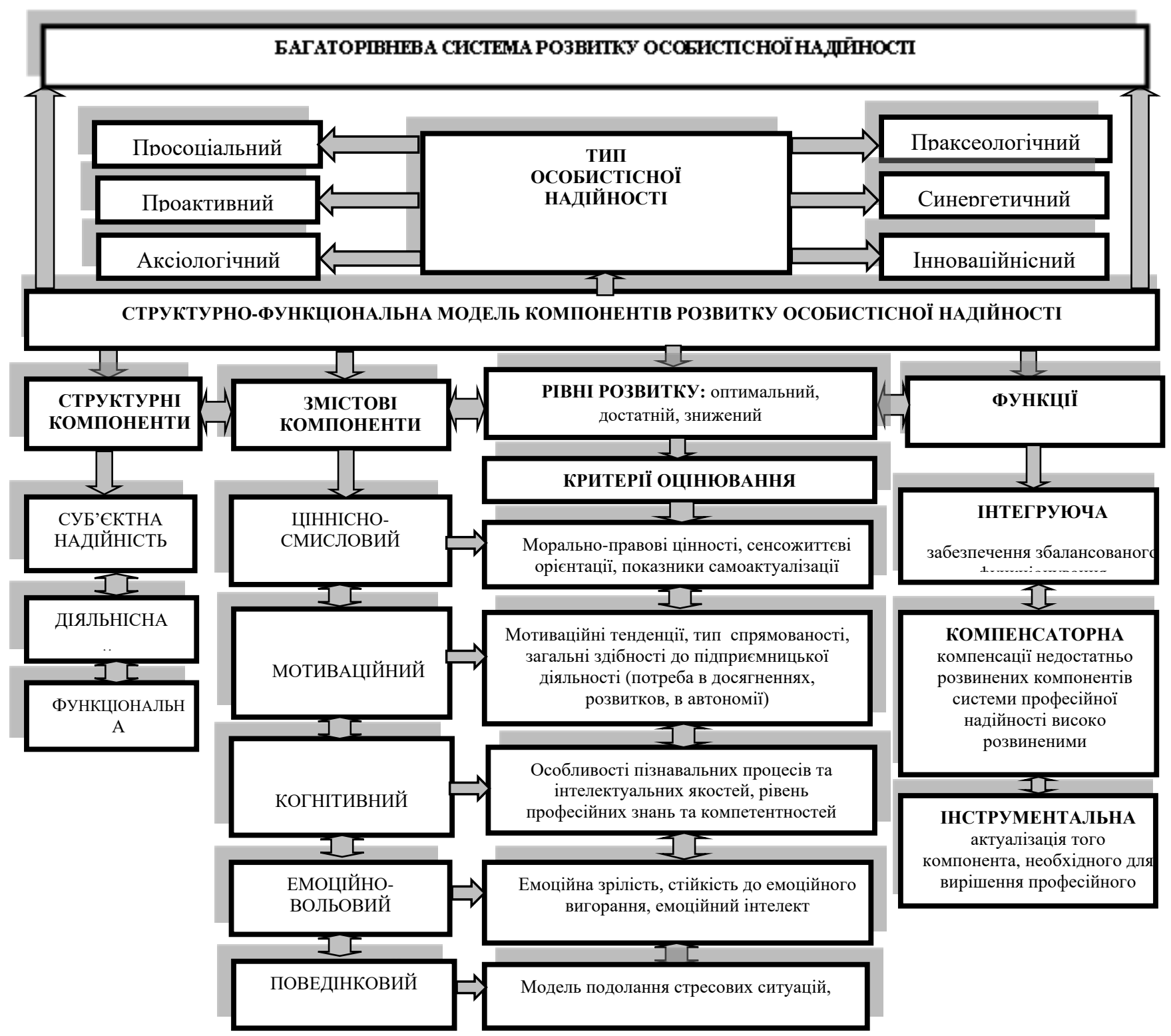

\section{Рис. 2. Функціональна модель розвитку компонентів особистісної надійності суб'сктів підприємницької діяльності}

Так, суб’єктна надійність включає в себе морально-правові та просоціальні, гуманістично-орієнтовані значення, які відповідають етиці обраної ними роботи і передбачають розуміння соціальної значущості та особистісної відповідальності за підсумками підприємницької роботи, соціальну, відомчу і групову нормативність поведінки як найважливішої умови успішності професійної діяльності та попередження порушень. Діяльнісна надійність визначає особистість як суб’єкта підприємницької діяльності й передбачає безпомилковість і своєчасність виконання професійних функцій у різних режимах та умовах праці. Діяльнісна надійність обумовлена включенням до 
структури особистості підприємця: професійних та спеціальних знань, умінь та навичок; досвіду реалізації бізнес-проектів і забезпечення їх ефективності та успішності. Функціональна надійність характеризує особистість як біологічного індивіда: відображає функціональний стан його організму, об’єм енергетичних ресурсів, необхідних для ефективного виконання трудової діяльності.

О.Л. Осадчук вважає, що визнаючи правомірність особливого, виділеного розгляду окремих підсистем надійності особистості, слід акцентувати їх зв'язок і взаємообумовленість: будучи самі системними утвореннями, вони отримують власну змістовну і активну визначеність тільки у цілісній структурі [738].

Відповідно до структури особистісної надійності суб’єктів підприємницької діяльності слід зарахувати такі змістові компоненти, як: ціннісно-смисловий, мотиваційний, когнітивний, емоційно-вольовий та поведінковий. Змістові компоненти обумовлюють розвиток i реалізацію особистісної надійності в діяльності [752].

Когнітивний компонент особистісної надійності підприємця є результатом пізнання і засвоєння змісту підприємницької діяльності та складання системи знання щодо персональних можливостей набуття професійного досвіду 3 урахуванням наявності чи відсутності необхідних для цього професійно важливих якостей та здібностей. Когнітивна складова передбачає певний рівень розвитку пізнавальних процесів, що складають інтелектуально-пізнавальну сферу суб’єкта, необхідних для успішної реалізації підприємницької діяльності. Розвиток інтелектуально-пізнавальної сфери передбачає розширення категоріальної та понятійної структури свідомості індивіда, що надає можливість набути навички інтерпретації отриманої інформації та іiі застосування в підприємницькій діяльності, підвищуючи якість виконання професійних функцій.

Емоційно-вольова складова особистісної надійності $€$ процесом відображення емоційного ставлення особистості до професійної діяльності або до окремих, професійно значущих якостей своєї особистості відповідно до потреб та мотивів. Показниками емоційно-вольової складової надійності 
особистості є: інтереси, самооцінка, задоволення професійною діяльністю, емпатія та емоційна стійкість. Далі детальніше зупинимося на характеристиці кожного з показників: інтереси мотивують до подальшого навчання, розвитку вмінь та навичок; самовідношення особистості стимулює професійний та особистісний саморозвиток та самовдосконалення; самооцінка відображає потенційні можливості та прагнення особистості; емпатія та емоційна стійкість відображають особистісну значимість всього, що відбувається в реальності та внутрішні переживання особистості. В основі переживань знаходиться ціннісносмислова перебудова свідомості підприємця.

Мотиваційна складова надійності підприємця є процесом відображення ступеня готовності працівника до виконання професійних дій, дотримання принципів та відповідної етики у професійній діяльності, відповідальності за правомірність дій. Рівень особистісної активності підприємців пов'язаний 3 такими якостями особистості як сила волі, цілеспрямованість, енергійність та витримка. Важливими складовими вольової регуляції поведінки $є$ самооцінка особистості підприємця, тип локалізації контролю, ціннісні орієнтації, рівень емоційного та інтелектуального розвитку, а також професійна рефлексія. Остання надає об'єктивного значення діяльності та призводить до усвідомлення впливу на процес професійної діяльності.

Ціннісно-смисловий компонент надійності характеризується усвідомленням своєї відповідальності перед моральними цінностями та ідеалами, що дозволяє суб'єктам підприємницької діяльності протистояти нормам вузькогрупової та егоїстичної моралі. Ціннісно-смислова сфера особистості вміщує в собі систему уявлень, особистісних конструктів, які наповнюють семантичний простір професійної свідомості, результатом чого $\epsilon$ формування образу «Я», образу «Професії», що сприяє самопізнанню, самовідношенню, самоідентичності.

Якісне рішення професійних завдань можливе за рахунок цілеспрямованого аналізу ситуації та ймовірних різновидів поведінки, вироблення стратегії вирішення проблемної ситуації, планування особистих 
вчинків 3 урахуванням неупереджених критеріїв, попереднього досвіду й наявних ресурсів, а також подолання несприятливих ситуацій у зв'язку iз завданням за рахунок мінімізації впливу емоційного стану на прийняття рішення та самоконтролю [741, с. 35].

При дослідженні об’єкта, як системи, кожен компонент описується не лише $з$ урахуванням його місця, але й ролі в цілому. Існування системи особистісної надійності здійснюється за допомогою реалізації властивих їй функцій. Функції особистісної надійності суб'єкта відображають його призначення, роль у підприємницькій діяльності. Стосовно системного підходу до вивчення надійності фахівця можуть бути виділені як загальні функції, властиві системі професійної надійності в цілому, так і специфічні функції іiі окремих компонентів. Особистісна надійність реалізується за допомогою трьох загальних системних функцій:

- інтегруюча - координація компонентів особистісної надійності як певної цілісності, що виявляється в забезпеченні збалансованого функціонування всіх іiі рівнів, кожен з яких час від часу виходить зі стану рівноваги, але система в цілому цей стан стабільності зберігає;

- інструментальна - актуалізація того компонента, який необхідний для вирішення актуального завдання, що стоїть перед підприємцем;

- компенсаторна - консолідується в заміні недостатньо розвинених компонентів надійності особистості більш розвиненими [738, с. 35].

Через психологічний механізм компенсації або деформації психофізичного ресурсу спостерігається така закономірність: чим менші показники психофізичного благополуччя, тим менш нормативною може бути поведінка в деяких ситуаціях поза нею. Так само як і поведінка, яка є нормативною в деяких ситуаціях професійної діяльності, може стати ненормативною в інших ситуаціях, тому нормативність оцінюється з інших позицій або носіями інших норм [752].

Таким чином, проблема становлення надійності суб'єктів підприємницької роботи повинна вирішуватися через дослідження тих особистих структур, що забезпечують стабільність і відповідний ступінь особистісно-функціонально- 
діяльнісних характеристик підприємців на важливих рівнях соціокультурного простору.

Особистісна надійність суб'єктів підприємницької діяльності включає в себе морально-правові та просоціальні, гуманістично-орієнтовані цінності, які відповідають етиці обраної ними професійної діяльності та усвідомлюють суспільну значущість і особисту відповідальність за підсумки підприємницької діяльності [759, с. 57-58].

Виділені змістові компоненти особистісної надійності в реальному життєвому просторі взаємозв'язані і взаємодетерміновані, обумовлюючи інтегральне особистісне утворення. Компоненти при входженні в ціле, з одного боку, втрачають певні характеристики, властивості, а з іншого - набувають нових властивостей. В якості базового компонента особистісної надійності виступають ціннісно-світоглядні орієнтації особистості. Вони утворюють фундамент змістової сторони надійності суб'єкта й виражають внутрішню основу його ставлення до дійсності.

Кожен компонент системи особистісної надійності володіє своїми локальними можливостями й, узятий окремо, не може повністю забезпечити ефективність функціонування підприємця. Лише їхня діалектична єдність дає можливість фахівцю досягти найкращих результатів. Проблеми у функціонуванні будь-якого 3 компонентів особистісної надійності завдають збитків системі в цілому. Рівень особистісної надійності суб’єкта підприємницької діяльності може бути визнаний оптимальним лише за умови високого рівня розвитку всіх складових даної структури.

Виділені психологічні компоненти особистісної надійності суб’єктів підприємницької діяльності ієрархічно збудовані, мають різну міру узагальненості й конкретизації на різних рівнях світогляду, розвитку підприємливості та типу надійності. Ефективність психологічних компонентів, щодо формування особистісної надійності, зростає, коли вони виступають єдиною взаємопов’язаною системою. 
Розвиток дослідження в цьому напрямі визначив необхідність виділення критеріїв для встановлення рівня розвитку особистісної надійності суб'єктів підприємницької діяльності. Відомо, що критерієм у системному аналізі є інструмент (спосіб) для порівняння альтернатив, тобто, будь-яка ознака, значення якої можна зафіксувати кількісно або якісно. Критерій - це об’ єктивна міра деякого явища, у нашому випадку - особистісної надійності фахівців соціономічної сфери діяльності. Як певна міра критерій повинен задовольняти умові адитивності. У змістовому плані до критеріїв висувають додаткові вимоги. Так, критерій має бути адекватний тому явищу, вимірювачем якого він слугує: у критерії має бути відображена природа вимірюваного явища й динаміка змін властивості, яку критерій виражає. Критерій має бути виражений однозначно: одні й ті самі фактичні значення різних явищ при застосуванні до них критерію повинні давати однакові кількісні значення величин, що вимірюються. Критерій має бути простим, тобто припускати найпростіші способи вимірювання [752]. Важливо, що можна використовувати декілька критеріїв, що описують одну ціль 3 різних боків і доповнюють один одного. 3 урахуванням методологічних і теоретичних підстав дослідження нами були розроблені кваліметричні характеристики оцінки показників розвитку особистісної надійності суб'єктів підприємницької діяльності. Вони представленні у таблиці 1.

На думку автора О.Л. Осадчук, розуміння розвитку надійності особистості як природного, тобто органічного феномена, що витікає з внутрішньої логіки руху системи зміни, зовсім не означає визнання некерованості даного процесу [738].

Таблиия 1

Критерії оцінки рівня розвитку особистісної надійності суб'єктів підприсмницької діяльності

\begin{tabular}{|c|c|c|c|}
\hline Рівні & \multicolumn{1}{|c|}{ Якісні характеристики } & $\begin{array}{l}\text { Оцінка } \\
\text { в балах }\end{array}$ \\
\hline \multicolumn{4}{|c|}{ Поведінкові характеристики } \\
\hline Оптимальний & $\begin{array}{l}\text { Високо розвинені поведінкові характеристики, які забезпечують } \\
\text { успішне виконання професійних завдань, дозволяють успішно } \\
\text { справлятися 3 професійною роллю. Використання переважно } \\
\begin{array}{l}\text { «просоціальних» стратегій подолання стресу. Провідними } \\
\text { моделями подолання стресових ситуацій є «вступ у соціальний } \\
\text { контакт» та «пошук соціальної підтримки». Домінуючими }\end{array}\end{array}$ \\
\hline
\end{tabular}




\begin{tabular}{|c|c|c|}
\hline & $\begin{array}{l}\text { типами реакцій на дію стресорів } \epsilon \text { «самоконтроль» та } \\
\text { «планування». Високий рівень особистісного адаптаційного } \\
\text { потенціалу. }\end{array}$ & \\
\hline Достатній & $\begin{array}{l}\text { Ключовими типами реакцій на дію стресорів є «прийняття } \\
\text { відповідальності» та «позитивна переоцінка». Використання } \\
\text { переважно «просоціальних» стратегій подолання стресу. } \\
\text { Провідними моделями подолання стресових ситуацій є «вступ у } \\
\text { соціальний контакт». Розвинені на достатньому рівні } \\
\text { поведінкові характеристики, які забезпечують успішне } \\
\text { виконання професійних завдань, дозволяють успішно } \\
\text { справлятися } 3 \text { професійною роллю. Низький рівень } \\
\text { особистісного адаптаційного потенціалу. }\end{array}$ & $7-5$ \\
\hline Знижений & $\begin{array}{l}\text { Використання таких стилів і стратегії свідомої соціальної } \\
\text { поведінки } 3 \text { подолання життєвих труднощів як } \\
\text { «дистанціювання» та «уникнення». Використовуються } \\
\text { переважно «прямі» та «пасивні» стратегії подолання стресу. } \\
\text { Провідними моделями подолання стресових ситуацій є } \\
\text { «імпульсивні дії» та «обережні дії». Відсутність виражених } \\
\text { поведінкових характеристик, які забезпечують успішне } \\
\text { виконання професійних завдань, рідко справляються з } \\
\text { професійною роллю. Низький рівень особистісного } \\
\text { адаптаційного потенціалу. }\end{array}$ & $4-1$ \\
\hline \multicolumn{3}{|c|}{ Когнітивні характеристики } \\
\hline Оптимальний & $\begin{array}{l}\text { Високий рівень розвитку пізнавальної сфери та інтелектуальних } \\
\text { якостей особистості, який виявляється у «інноваторському» } \\
\text { когнітивному стилі. Переважно характерним є наявність } \\
\text { креативного, образного та знакового типу мислення. Високий } \\
\text { рівень розвитку за композитною оцінкою соціального інтелекту. } \\
\text { Сформовані підприємницькі компетентності у сферах: } \\
\text { «трансформації в дії» (взяття на себе ініціативи, планування та } \\
\text { управління, робота } 3 \text { неоднозначністю, невизначеністю та } \\
\text { ризиками, співпраця з іншими особами, навчання через досвід); } \\
\text { «ресурси» (самосвідомість і самоефективність, мотивація та } \\
\text { наполегливість, мобілізація ресурсів, фінансова та економічна } \\
\text { грамотність, мобілізація інших осіб); «ідеї та можливості» } \\
\text { (креативність, оцінювання ідей, етичне та обгрунтоване } \\
\text { мислення, виявлення можливостей, прогнозування). }\end{array}$ & $10-8$ \\
\hline Достатній & $\begin{array}{l}\text { Необхідний рівень розвитку пізнавальної сфери та } \\
\text { інтелектуальних якостей особистості, який виявляється у слабко } \\
\text { вираженому «адапторському» когнітивному стилі. Переважно } \\
\text { характерним є наявність символічного типу мислення. Вище } \\
\text { середнього - рівень розвитку за композитною оцінкою } \\
\text { соціального інтелекту. Сформовані підприємницькі } \\
\text { компетентності у сферах: «трансформації в дії» (взяття на себе } \\
\text { ініціативи, планування та управління, робота з неоднозначністю, } \\
\text { невизначеністю та ризиками); «ресурси» (мотивація та } \\
\text { наполегливість, мобілізація ресурсів, фінансова та економічна } \\
\text { грамотність); «ідеї та можливості» (оцінювання ідей, виявлення } \\
\text { можливостей, прогнозування). }\end{array}$ & $7-5$ \\
\hline
\end{tabular}




\begin{tabular}{|c|c|c|}
\hline Знижений & $\begin{array}{l}\text { Інтелектуально-пізнавальні процеси знаходяться на середньому } \\
\text { рівні, що виявляється в домінуванні «адапторського» } \\
\text { когнітивного стилю. Переважно характерним є наявність } \\
\text { знакового типу мислення. Середній рівень розвитку за } \\
\text { композитною оцінкою соціального інтелекту. Не сформовані } \\
\text { підприємницькі компетентності у сфері: «трансформації в дії» } \\
\text { (взяття на себе ініціативи, планування та управління, робота } 3 \\
\text { неоднозначністю, невизначеністю та ризиками, співпраця } 3 \\
\text { іншими особами, навчання через досвід); «ресурси» } \\
\text { (самосвідомість і самоефективність, мобілізація інших осіб); } \\
\text { «ідеї та можливості» (креативність, етичне та обгрунтоване } \\
\text { мислення, прогнозування). }\end{array}$ & $4-1$ \\
\hline \multicolumn{3}{|c|}{ Ціннісно-смислові характеристики } \\
\hline Оптимальний & $\begin{array}{l}\text { Високий рівень моральної нормативності - високий рівень } \\
\text { соціалізації, адекватна оцінка своєї ролі в колективі, орієнтація } \\
\text { на дотримання загальноприйнятих норм поведінки. Рівень } \\
\text { морально-правової надійності високий. Високий рівень } \\
\text { ціннісних орієнтацій у кар’єрі за показником «Служіння», } \\
\text { «Професійна компетентність» та «Підприємництво». За } \\
\text { смисложиттєвими орієнтаціями характерна висока насиченість } \\
\text { життя, задоволеність самореалізацією, відчуття продуктивності } \\
\text { й осмисленості проживання, уявлення про себе як про сильну } \\
\text { особистість, яка має достатню свободу вибору, щоб побудувати } \\
\text { своє життя відповідно до своїх цілей і уявлень про його сенс, } \\
\text { усвідомленість життя тісно пов'язана з внутрішнім локусом } \\
\text { контролю. Високий рівень самоактуалізації. }\end{array}$ & $10-8$ \\
\hline Достатній & $\begin{array}{l}\text { Середній рівень морально-правової надійності. Високий рівень } \\
\text { ціннісних орієнтацій у кар'єрі за показником «Менеджмент» та } \\
\text { «Підприємництво». За смисложиттєвими орієнтаціями } \\
\text { характерна відсутність цілей у майбутньому, які надають життю } \\
\text { осмисленості, спрямованості й тимчасову перспективу, } \\
\text { уявлення про себе як про сильну особистість, яка має достатню } \\
\text { свободу вибору, щоб побудувати своє життя відповідно до своїх } \\
\text { цілей і уявленнями про його сенс, усвідомленість життя тісно } \\
\text { пов’язана } 3 \text { внутрішнім локусом контролю. Високий рівень } \\
\text { самоактуалізації. }\end{array}$ & $7-5$ \\
\hline Знижений & $\begin{array}{l}\text { Схильність сприймати образ підприємця, спираючись на } \\
\text { індивідуальні особливості та професійну оцінку діяльності. } \\
\text { Наявність прагматичної та корисливої стадії розвитку морально- } \\
\text { правової надійності. Високий рівень ціннісних орієнтацій у } \\
\text { кар’єрі за показником «Виклик», «Автономія (незалежність)» та } \\
\text { «Інтеграція стилів життя». За смисложиттєвими орієнтаціями } \\
\text { характерна захопленість нездійсненими проектами, плани яких } \\
\text { не мають реальної опори в сьогоденні і не підкріплюються } \\
\text { особистою відповідальністю за їх реалізацію; обрання життєвої } \\
\text { позиції, в основі якої лежить уявлення про насолоду, як мету } \\
\text { людського існування; невіра у свою здатність контролювати } \\
\text { події власного життя; невпевненість у принциповій можливості } \\
\text { самостійного здійснення життєвого вибору. Середній та низький } \\
\text { рівень самоактуалізації. }\end{array}$ & $4-1$ \\
\hline
\end{tabular}




\begin{tabular}{|c|c|c|}
\hline \multicolumn{3}{|c|}{ Мотиваційні характеристики } \\
\hline Оптимальний & $\begin{array}{l}\text { Провідними мотиваційними тенденціями є прагнення до } \\
\text { прийняття та прагнення до взаємодії і служіння. Домінуючий } \\
\text { тип спрямованості - спрямованість на діяльність, на завдання. } \\
\text { Розвинуті на високому рівні загальні здібності до } \\
\text { підприємницької діяльності: «потреба в досягненнях } \\
\text { (подальшому розвитку)», «потреба в незалежності / автономії», } \\
\text { «схильність до творчості (творчі здібності / нахили)», «уміння } \\
\text { йти на розумний (зважений) ризик», «цілеспрямованість та } \\
\text { рішучість». }\end{array}$ & $10-8$ \\
\hline Достатній & $\begin{array}{l}\text { Мотиваційний профіль характеризується орієнтацією на } \\
\text { альтруїстичну мотивацію, мотивацію позитивного ставлення до } \\
\text { людей, спілкування і прагненням допомагати людям. } \\
\text { Домінуючий тип спрямованості - спрямованість на спілкування. } \\
\text { Висока пізнавальна та трудова мотивація. Розвинуті загальні } \\
\text { здібності до підприємницької діяльності: «потреба в } \\
\text { досягненнях (подальшому розвитку)», «потреба в незалежності } \\
\text { / автономії». }\end{array}$ & $7-5$ \\
\hline Знижений & $\begin{array}{l}\text { Мотиваційний профіль характеризується, у першу чергу, } \\
\text { гедоністичними, егоцентричними тенденціями. Домінуючий } \\
\text { тип спрямованості на себе. Високий рівень орієнтації на } \\
\text { матеріальну мотивацію, пізнавальну мотивацію, мотивацію } \\
\text { прагнення до досконалості та низький рівень уникнення } \\
\text { неприємностей. Розвинуті такі загальні здібності, як потреба в } \\
\text { незалежності / автономії та потреба в досягненні. }\end{array}$ & $4-1$ \\
\hline \multicolumn{3}{|c|}{ Емоційно-вольові характеристики } \\
\hline Оптимальний & $\begin{array}{l}\text { Високий рівень емоційної зрілості, саморегуляція свого } \\
\text { емоційно-вольового стану, толерантність у спілкуванні й } \\
\text { поведінці. Дуже високий загальний рівень емоційного інтелекту. } \\
\text { Розвинуті на високому рівні загальні здібності до } \\
\text { підприємницької діяльності: «уміння йти на розумний } \\
\text { (зважений) ризик», «цілеспрямованість та рішучість». }\end{array}$ & $10-8$ \\
\hline Достатній & $\begin{array}{l}\text { Достатньо високий рівень емоційної зрілості, саморегуляція } \\
\text { свого емоційно-вольового стану, толерантність в спілкуванні і } \\
\text { поведінці. Високий загальний рівень емоційного інтелекту. } \\
\text { Розвинуті загальні здібності до підприємницької діяльності: } \\
\text { «вміння йти на розумний (зважений) ризик», } \\
\text { «цілеспрямованість та рішучість». }\end{array}$ & $7-5$ \\
\hline Знижений & $\begin{array}{l}\text { Середній та низький рівень емоційної зрілості, емоційного } \\
\text { інтелекту, саморегуляція свого емоційно-вольового стану, } \\
\text { толерантність у спілкуванні й поведінці. }\end{array}$ & $4-1$ \\
\hline
\end{tabular}

Для розуміння сутності розвитку надійності може виявитися плідним перенесення в галузь iї дослідження широко відомого уявлення про зону найближчого розвитку [760].

Згідно цього надійність має свій рівень актуального, тобто досягнутого, й реалізованого розвитку. Проектування ж зони найближчого, тобто можливого 
розвитку i траєкторії руху до iï верхнього кордону - важливе завдання управління процесом розвитку системи особистісної надійності [738].

Згідно формули О.М. Леонтьєва - «внутрішнє діє через зовнішнє і цим само себе змінює» - джерело перетворень системи особистісної надійності знаходиться в самій системі [761]. Рушійними силами розвитку особистісної надійності суб’єктів підприємницької діяльності є зовнішні протиріччя невідповідності між об’ єктивною реальністю та її суб’ єктивним віддзеркаленням підприємцем, а також внутрішні протиріччя в самій системі особистісної надійності - розбіжності між цільовими функціями окремих ii підсистем (їх різна спрямованість). Вирішення цих протиріч утворює процес розвитку особистісної надійності суб'єктів підприємницької діяльності і є основним змістом управління цим процесом.

Розгляд питання багаторівневості системи розвитку особистісної надійності через призму концепції вертикального розвитку Ж. Гебстера [724] та соціально-еволюційної теорії спіральної динаміки К. Грейвза [726] дозволяє прослідкувати взаємозв’язок між парадигмами свідомості, підприємливістю як компетентності та типами особистісної надійності.

Знання, накопичені людством протягом багатьох тисяч років, усі культури, народжені людьми, усі ціннісні орієнтири однаково активно присутні в нашому тепер уже загальному інформаційному полі, породжуючи і руйнівні потрясіння, i нові форми людяності. На глобальному просторі смислового хаосу народжуються і вмирають 3 дивовижною швидкістю нові ідеї. Ми живемо в насиченому часі, коли протягом життя одного покоління встигають змінюватися цілі епохи. Тому усвідомлення множинності світів - перший крок до усвідомлення своєї парадигми мислення і властивих їй обмежень, а значить стимул до подальшого розвитку, відкриття для себе нових, вищих світів і відкриття себе для них. Кожна парадигма мислення, кожен рівень повинен бути освоєний і заповнений, адже він надає людині важливих життєвих навичок, наскрізних компетентностей, без яких вона не зможе далі розвиватися [728]. 
Так, EntreComp визначає підприємливість як наскрізну компетентність, яка затребувана в усіх сферах життя: від турботи про особистісне благополуччя та становлення до реалізації соціальної ролі громадянина в житті суспільства, входження (повторного входження) на ринок праці в якості співробітника організації або ж самозайнятої особи - підприємця. Це поняття базується на широкому визначенні підприємливості, яке грунтується на створенні культурної, соціальної чи економічної цінності [762].

Спираючись на модель становлення EntreComp, яка виходить 3 того, що підприємливість розвивається в процесі діяльності окремих осіб чи установ 3 метою створення благ для інших, сутність підприємливості складається 3 двох аспектів: 1) становлення більшої автономії та відповідальності у втіленні думок і ймовірностей для створення цінностей; 2) становлення можливості генерувати значення - від нескладних та передбачуваних контекстів і до специфічних типів середовища, яке щодня змінюється.

Типи розвитку особистісної надійності суб'єктів підприємницької діяльності, спираючись на теорію К. Грейвза, можна охарактеризувати залежно від прояву різних рівнів світогляду та розвитку підприємливості. Нами було визначено взаємозв'язок рівнів світогляду (за моделлю спіральної динаміки), рівнів підприємливості (за моделлю поступу EntreComp) та типів особистісної надійності (табл. 2). Психосоціокультурний прояв феномена особистісної надійності, як виду соціально-економічної активності суб'єктів підприємницької діяльності, неможливий з першого по третій рівні свідомості, яким притаманні, відповідно, інстинктивна, племена та егоцентрична парадигми мислення.

Особистісна надійність за «праксеологічним» типом знаходить свій прояв на четвертому та п’ятому рівнях світогляду, згідно теорії спіральної динаміки, і відповідає основному й середньому рівню розвитку підприємливості, згідно моделлю поступу EntreComp. Цей тип надійності забезпечує ефективне управління діяльністю через іiі всебічний самоаналіз, самооцінювання, цілеспрямоване моделювання умов і засобів удосконалення на основі синтезу теоретичних знань та емпіричного досвіду. Він відображає залежність 
результатів роботи, насамперед, від попередньої ретельної підготовки до іiі виконання, ступень підготовленості дій у широкому розумінні, що охоплює оволодіння знаннями, свідомий вибір засобів, методів аналізу й регулювання, критерії емоційного і практичного оцінювання результатів.

Особистісна надійність за «аксіологічним» та «просоціальним» типом знаходить свій прояв на шостому рівні світогляду, згідно теорії спіральної динаміки, й відповідає вищому рівню розвитку підприємливості, згідно моделлю поступу EntreComp.

Так, особистісна надійність за «аксіологічним» типом передбачає розвиненість гуманістично спрямованої системи ціннісних орієнтацій, що забезпечує надійність особистості й формування світоглядних позицій, ціннісносвітоглядних ідеалів і стандартів: наявність чіткої системи індивідуальних норм поведінки; сформованість соціальної відповідальності та зрілості. Цим визначається особистісний зміст підприємницької діяльності.

Особистісна надійність за «просоціальним» типом, у першу чергу, обумовлює просоціальні поведінки суб'єктів підприємницької діяльності, яка за своїм змістом, механізмами й формами має багато різновидів. До основних належать: альтруїстична та допомагаюча поведінка, співробітництво, емпатія, гуманні взаємини; суто в економічній площині це фандрайзинг, донорство, благодійність, меценатство.

Особистісна надійність за «просоціальним» типом забезпечує здійснення соціального підприємництва, заснованого на соціальній відповідальності та соціальному партнерстві як протидії затяжній соціально-економічній кризі в суспільстві.

Його орієнтованість на високе споживання та матеріальне процвітання, прагматичність та конкуренцію ринкових відносин, прагнення до власного благополуччя при ігноруванні інтересів інших людей продукує зростання егоїстичної домінанти в соціальній поведінці та руйнування фундаментальних морально-етичних цінностей, ідеалів. Тому можна констатувати, що повноцінне 
життя людини і як громадянина, і як особистості неможливе без набуття особистісних смислів просоціального рівня.

Особистісна надійність за «проактивним» та «синергетичним» типом знаходить свій прояв на сьомому рівні світогляду, згідно теорії спіральної динаміки, і відповідає експертному рівню розвитку підприємливості, згідно моделлю поступу EntreComp. «Проактивний» тип виявляється в усвідомленні суб'єктом своїх глибинних цінностей та цілей, підпорядкованості дій життєвим принципам незалежно від умов та обставин, прийнятті відповідальності за себе і своє життя, у таких поведінкових особливостях, як: ініціативність і активність; переконаність у наявності вибору, можливості щось змінити; готовність брати відповідальність; принциповість, цілеспрямованість; зміна (або вибір) обставин під свої завдання.

Особистісна надійність за «синергетичним» типом характеризує особистісний розвиток суб'єкта підприємницької діяльності не тільки як поступовий, лінійний, безконфліктний процес, а як такий, що супроводжується суперечностями, які зумовлюють трансформацію ціннісних орієнтацій, самопізнавальну й самовиховну активність. 
Таблиия 2

Взаємозв'язок рівнів світогляду за моделлю спіральної динаміки, рівнів підприсмливості за моделлю поступу

EntreComp та типів особистісної надійності

\begin{tabular}{|c|c|c|c|c|c|}
\hline $\begin{array}{c}\text { Рівень } \\
\text { світогляду }\end{array}$ & Характеристика цінностей & $\begin{array}{c}\text { Парадигма } \\
\text { мислення }\end{array}$ & Стратегії організації діяльності & $\begin{array}{c}\text { Рівні } \\
\text { підприсмливості } \\
\text { за моделлю } \\
\text { поступу } \\
\text { EntreComp } \\
\end{array}$ & $\begin{array}{c}\text { Типи } \\
\text { особистісної } \\
\text { надійності }\end{array}$ \\
\hline $\begin{array}{l}\text { Перший } \\
\text { (бежевий } \\
\text { колір) }\end{array}$ & Задоволення фізіологічних потреб & Інстинктивна & $\begin{array}{c}\text { Інстинктивна стратегія виживання. } \\
\text { Етична стратегія - це те, що сприяє } \\
\text { виживанню. }\end{array}$ & \multirow{3}{*}{$\begin{array}{c}\text { Покладання на } \\
\text { підтримку інших }\end{array}$} & \\
\hline $\begin{array}{c}\text { Другий } \\
\text { (фіолетовий } \\
\text { колір) }\end{array}$ & $\begin{array}{c}\text { Людина зв'язана безліччю табу, } \\
\text { правил та обмежень, позбавлена } \\
\text { індивідуального мислення та } \\
\text { права на вчинок. Сімейні, родинні, } \\
\text { кланові зв'язки мають абсолютну } \\
\text { силу й містичне забарвлення. Рід, } \\
\text { як група, збільшує вірогідність } \\
\text { виживання та має більше } \\
\text { значення, ніж окремий його член. } \\
\text { Мають значну вагу дружба, } \\
\text { кумівство. }\end{array}$ & Племінна & $\begin{array}{c}\text { Внутрішньокорпоративні стратегії: } \\
\text { формування ритуалів та обрядів, } \\
\text { установлення табу, сильні традиції, } \\
\text { сімейність всередині компанії }\end{array}$ & & \\
\hline $\begin{array}{c}\text { Третій } \\
\text { (червоний } \\
\text { колір) }\end{array}$ & $\begin{array}{c}\text { Життя, як у джунглях, де сильний } \\
\text { перемагає слабкого. Природа - це } \\
\text { щось таке, що може бути } \\
\text { завойоване }\end{array}$ & Егоцентрична & $\begin{array}{c}\text { Жорстокі конкурентоспроможні } \\
\text { ринкові стратегії, рейдерство, рекет. } \\
\text { Зовнішній тиск, імпульсивність у } \\
\text { схваленні рішень, виживання ціною } \\
\text { життя інших людей, співробітники } \\
\text { - ніхто в компанії не товаришує, усі } \\
\text { відносини прагматичні }\end{array}$ & & \\
\hline
\end{tabular}


Продовження таблиці 2

\begin{tabular}{|c|c|c|c|c|c|}
\hline \multirow[b]{2}{*}{$\begin{array}{c}\text { Рівень } \\
\text { світогляду }\end{array}$} & \multirow[b]{2}{*}{ Характеристика цінностей } & \multirow[b]{2}{*}{$\begin{array}{c}\text { Парадигма } \\
\text { мислення }\end{array}$} & \multirow[b]{2}{*}{ Стратегії організації діяльності } & \multirow[b]{2}{*}{\begin{tabular}{|c|} 
Рівні \\
підприємливост \\
i \\
за моделлю \\
поступу \\
EntreComp \\
\end{tabular}} & \multirow[b]{2}{*}{$\begin{array}{c}\text { Типи } \\
\text { особистісної } \\
\text { надійності }\end{array}$} \\
\hline & & & & & \\
\hline $\begin{array}{c}\text { Четвертий } \\
\text { (синій колір) }\end{array}$ & $\begin{array}{c}\text { Усе контролюється вищою } \\
\text { силою, яка карає зло і } \\
\text { нагороджує добро, стежить за } \\
\text { дотриманням правил і виявляє } \\
\text { відхилення від них }\end{array}$ & $\begin{array}{c}\text { Авторитарна, } \\
\text { патріотична }\end{array}$ & $\begin{array}{c}\text { Стратегії регламентації діяльності } \\
\text { компанії: опис бізнес-процесів, } \\
\text { посадові інструкції, положення, } \\
\text { правила, методики, корпоративні } \\
\text { стандарти }\end{array}$ & $\begin{array}{c}\text { Покладання на } \\
\text { підтримку інших }\end{array}$ & \multirow{2}{*}{ Праксеологічний } \\
\hline $\begin{array}{c}\text { П'ятий } \\
\text { (помаранчевий } \\
\text { колір) }\end{array}$ & $\begin{array}{c}\text { Світ повний ресурсів і } \\
\text { можливостей зробити все } \\
\text { кращим і досягти процвітання }\end{array}$ & $\begin{array}{c}\text { Матеріалісти } \\
\text { чна }\end{array}$ & $\begin{array}{c}\text { Досягнення успіху, важливий } \\
\text { імідж і зростання доходів; це } \\
\text { супроводжується упровадженням } \\
\text { нових технологій, обгрунтуванням } \\
\text { будь-якого рішення мовою чисел }\end{array}$ & $\begin{array}{c}\text { Розвиток } \\
\text { незалежності }\end{array}$ & \\
\hline $\begin{array}{l}\text { Шостий } \\
\text { (зелений } \\
\text { колір) }\end{array}$ & $\begin{array}{c}\text { Основними цінностями є } \\
\text { гармонія і взаємовідносини. } \\
\text { Оточення, в якому людина } \\
\text { може знайти любов і виконати } \\
\text { своє призначення. }\end{array}$ & $\begin{array}{c}\text { Згоди, } \\
\text { консенсус } \\
\text { міжособистіс } \\
\text { них зв'язків }\end{array}$ & $\begin{array}{l}\text { Упровадження корпоративної } \\
\text { соціальної відповідальності, } \\
\text { розробка соціальних пакетів, } \\
\text { відкриття благодійних фондів }\end{array}$ & Відповідальність & $\begin{array}{l}\text { Просоціальний, } \\
\text { аксіологічний }\end{array}$ \\
\hline $\begin{array}{c}\text { Сьомий } \\
\text { (жовтий колір) }\end{array}$ & $\begin{array}{c}\text { Найбільшими цінностями, } \\
\text { важливішими за ранг і статус, } є \\
\text { компетентність, незалежність, } \\
\text { свобода, гідність. Хаос, зміни є } \\
\text { нормою, а невизначеність } \\
\text { прийнята як стан буття }\end{array}$ & $\begin{array}{l}\text { Системності } \\
\text { та інтеграції }\end{array}$ & $\begin{array}{c}\text { Розробка декількох сценаріїв } \\
\text { розвитку компанії, принцип } \\
\text { самостійності структурних } \\
\text { одиниць, постійне навчання для } \\
\text { оптимізації процесів }\end{array}$ & \multirow{2}{*}{$\begin{array}{l}\text { Керування } \\
\text { зміною, } \\
\text { інновацією та } \\
\text { зростанням }\end{array}$} & $\begin{array}{l}\text { Проактивний, } \\
\text { синергетичний }\end{array}$ \\
\hline $\begin{array}{l}\text { Восьмий } \\
\text { (бірюзовий } \\
\text { колір) }\end{array}$ & $\begin{array}{c}\text { Баланс взаємопов’язаних сил, } \\
\text { де управління ризиками } \\
\text { знаходиться в руках людини }\end{array}$ & Холістична & $\begin{array}{c}\text { Глобальні стратегії, колективний } \\
\text { розум, створення глобальної } \\
\text { мережі }\end{array}$ & & Інноваційнісний \\
\hline
\end{tabular}


«Інноваційнісний» тип особистісної надійності суб’єктів підприємницької діяльності знаходить свій прояв на восьмому рівні світогляду, згідно теорії спіральної динаміки, і відповідає експертному рівню розвитку підприємливості, згідно моделлю поступу EntreComp.

«Інноваційнісний» тип особистісної надійності суб’єктів підприємницької діяльності відповідає найвищому експертному рівню розвитку підприємливості - управління зміною, інновацією і зростанням завдяки компетентностям, необхідних для реагування на складні виклики життя, середовища, яке постійно міняється і має високий рівень прогнозованості (розширення) і сфокусованість на нових викликах шляхом отримання нових знань, досліджень, розвитку та інноваційних здібностей для досягнення майстерності i трансформації соціокультурного простору.

Рівні світогляду, або ціннісні комплекси, що включають у себе духовні вірування, культурні ідеї, моральні принципи, моделі навчання тощо, 3'являються по мірі виникнення потреби в них у процесі соціокультурної еволюції.

Кожна парадигма мислення, кожен рівень повинен бути освоєний i заповнений, адже він надає людині важливих життєвих навичок, наскрізних компетентностей, без яких вона не зможе далі розвиватися. Цьому сприяє навчальний процес майбутніх фахівців [763].

Щодо питання особистісної надійності підприємців, то такою наскрізною компетентністю є підприємливість, яка грунтується на усвідомленні створення культурної, соціальної чи економічної цінності для інших. Створення цінності це узагальнюючий підсумок людської діяльності через втілення цілеспрямованих дій.

Таким чином, навчання майбутніх фахівців активізує розвиток як їх професіоналізму, так і особистісних якостей. Відповідно до цього навчання майбутніх підприємців розвиває одночасно їх як суб’єктів підприємницького середовища так і колективної взаємодії. Як член майбутнього підприємницького колективу він навчається бути проектувальником, конструктором, організатором 
i безпосереднім учасником у взаємодії, а також носієм певної особистісної позиції, що припускає навчитися необхідності проявляти фахівцем професійної надійності. Як суб'єкт підприємницької діяльності, майбутній підприємець повинен володіти відповідними етичними нормами, способами й засобами реалізації професійної надійності. На підставі зазначеного у майбутніх фахівців формується інтерес до розвитку професійної надійності як суб’єктів підприємницької діяльності.

Висновки.

1. Дослідження показало, що навчання розвитку особистісної надійності формує іiі як особливий феномен, в якому на суб'єктному рівні виявляється інтегративні якості підготовленості майбутнього фахівця до досягнення позитивних підсумків роботи у сфері людина-людина.

2. Моделювання стосовно проблеми розвитку особистісної надійності у навчальному процесі призводить до розуміння того, що розвиток цього феномену являє собою не пасивну інтеграцію впливу зовнішніх і внутрішніх умов існування особистості, а $є$ результатом навчання способам досягнення адаптивних можливостей $\mathrm{i}$ розширення репертуару стратегії поведінки подолання критичних ситуацій, які формуються в індивіда у процесі навчання професійної та особистісної самореалізації.

3. У досліджені виявлено, що навчання розвитку i формуванню особистісної надійності майбутніх підприємців дозволяє їм проявляти активну діяльність, особистісну надійність та спільність у взаємодії. Навчання професійної діяльності підприємців $є$ інтерсуб'єктивне, а формування професійної надійності грунтується на позитивному самовизначенні у взаємодії, у професійній спільності, що обумовлено розвитком підприємців у колективній діяльності, яка грунтується на позитивному самовизначенні, самоорганізації, самосвідомій та професійній діяльності. 